\title{
Corporate governance and IPO underpricing: evidence from the italian market
}

\author{
Emanuele Teti ${ }^{1}$ D $\cdot$ Ilaria Montefusco ${ }^{2}$
}

Accepted: 4 January 2021 / Published online: 27 March 2021

(C) The Author(s) 2021

\begin{abstract}
This paper aims to analyse the impact of firms' corporate governance characteristics on the degree of first-day returns (i.e., underpricing) in the Italian initial public offering (IPO) market. In particular, this work investigates the impacts of the characteristics of boards of directors (BoDs) and ownership structure on the underpricing of newly offered shares. By studying a sample of 128 Italian IPOs between 2000 and 2016, it is concluded that corporate governance characteristics affect the degree of first-day returns following a company's IPO. More specifically, the size of the BoD negatively affects underpricing, while the ownership of institutional investors and board members has a positive effect on the degree of underpricing. Conversely, no significant evidence is found with regard to board independence, the number of female directors in the boardroom, the implementation of stock option plans and ownership concentration.
\end{abstract}

Keywords Corporate governance $\cdot$ Ipos $\cdot$ Returns $\cdot$ Board of directors $\cdot$ Ownerhsip structure

\section{Introduction}

The IPO underpricing phenomenon is one of the most diffuse and complex issues in the financial world. Several studies and reports have found proof of underpricing in more than 50 countries. Developing countries are those countries recording the highest degrees of underpricing. However, this phenomenon is also significant in

Emanuele Teti

emanuele.teti@sdabocconi.it

1 Università Di Pisa, Via Cosimo Ridolfi, 10 - 56124, Pisa, Italy

2 Bocconi University, Via Sarfatti 25, 20136, Milan, Italy 
more developed countries, where capital markets work at a higher efficiency level. For instance, UK and US markets report average first-day returns of $15.8 \%$ and $16.8 \%$, respectively, ${ }^{1}$ thus demonstrating that while market efficiency can reduce the extent of underpricing, this condition alone cannot void it. Even though the roots of underpricing date back to the last decades of the twentieth century, this topic is still of great interest to market participants because of the massive transfer of wealth from a company issuing an offer to acquiring investors, as a consequence of firms' IPOs. Due to the great economic importance of first-day returns, financial researchers have tried and are currently trying to identify the key drivers of underpricing and understand whether issuer firms can affect its degree by leveraging specific variables-those that are either internal or external to the company itself.

Previous research concerning underpricing showed that it is influenced by the characteristics of companies' corporate governance, among several other determinants. This relationship derives from the oldest and strongest theories about underpricing that recognize asymmetric information as the main factor responsible for high first-day returns (Allen and Faulhaber 1989; Grinblatt and Hwang 1989; Welch 1989; Katherine Spiess and Pettway 1997). According to the signalling literature (Ibbotson and Jaffe 1975; Welch 1989; Grinblatt and Hwang 1989), underpricing is a powerful tool for signalling the quality of a company to investors and providing them with the possibility of distinguishing good companies from bad companies: low-quality firms cannot afford to leave money on the table when going public because they will not be able to make up for this loss in the future (Grinblatt and Hwang 1989). Corporate governance rules affect the degree of information asymmetry between shareholders and managers, i.e., between the principal and agent, and between controlling and minority shareholders (Hermalin and Weisbach 1988; Pearce and Zahra 1992; MacAvoy and Millstein 1999; Dey 2008). By influencing the relationships among the main actors in a firm, corporate governance also acts as a signalling tool for an external investor, reducing information asymmetry between the issuer and potential buyers in an IPO. Therefore, corporate governance impacts the degree of underpricing in IPOs, which is an alternative signalling means available to companies that want to become public.

Despite the large number of studies and research addressing corporate governance in relation to IPO underpricing, the evidence remains extremely mixed to date. It is still unclear which variables in the corporate governance area actually influence the first-day returns of a stock as well as the sign of this relation. Furthermore, most of the research conducted on IPOs has focused only on a small number of variables, preventing the results from accounting for a wider view of corporate governance and underpricing. In addition, these papers have focused either on the main stock exchange markets, i.e., the US and UK, or on the least developed countries.

This research aims to enrich the current literature with a study on Italian IPOs over a timeframe of 17 years, from 2000 to 2016. To date, the Italian market has not been explored in depth, and few studies conducted on Italian IPOs have reported data collected prior to 2011. The contribution of this paper is in terms of both up-to-date

$\overline{1}$ Source: "Initial Public Offerings: International Insights", 2019. 
data collection and investigation of this market, which is almost unexplored. Moreover, this work aggregates several diverse corporate governance and ownership structure variables to develop a broader and more accurate perspective of this matter. The research questions addressed are as follows. Does corporate governance affect IPO underpricing in the Italian market? Is investors' willingness to pay for newly offered shares influenced by firms' corporate governance decisions? To answer these questions, a cross-sectional sample of 128 Italian companies that went public from the 1st of January 2000 to the 31 st of December 2016 was analysed throughout the estimation of OLS regression models. The results showed that board size is negatively and significantly related to underpricing, while institutional investors' ownership and board ownership have a positive and statistically significant effect. These findings support signalling theory, which considers underpricing a tool for reducing the asymmetric information between an issuer and potential investors and signalling their high quality. While board size acts as a substitute tool for a company to signal its good quality, its increase leads to a decrease in underpricing, and the intensification of institutional investors' presence and board ownership exacerbates asymmetric information between the issuer and the investor, leading to an increase in underpricing. This paper is organized as follows. Section 2 discusses previous papers that have contributed to the financial literature on underpricing. Section 3 provides an overview of the Italian IPO market. In Sect. 4, research hypotheses are introduced. Section 5 describes the methodology, with details on the data collection activity, descriptive statistics, employed variables and regression models. Section 6 presents the empirical analysis and summarizes the obtained results. Finally, in Sect. 7, a conclusion incorporating the limitations of this research and suggestions for future studies is presented.

\section{Literature review}

\subsection{Asymmetric information theories}

Most studies find asymmetric information to be responsible for underpricing in the issuance of new shares in the equity market. Information asymmetry can be encountered at different levels. The first identified type is that between an issuer and investors. Ibbotson and Jaffe (1975) was the first to analyse the relationship between this asymmetry and the underpricing phenomenon, developing the so-called signalling literature. According to Ibbotson, the issuing firm decides to underprice the IPO to "leave a good taste in investors' mouths". Welch (1989) scrutinized this theory and reshaped it, explaining that the issuer deliberately underprices an offer to guarantee successful fundraising through future seasoned equity offerings. This theory has been called signalling theory since it involves valuable firms being incentivized to underprice their initial share offer to signal their high quality. Grinblatt and Hwang (1989) observed that underpricing is positively related to the intrinsic value of an issuing firm; it is an instrument used by good firms to reduce the information asymmetry between them and investors and to signal their high value. 
The second type of information asymmetry is between different categories of investors. One of the best-known models of asymmetric information is the winner's curse model, promoted by Rock (1986), who applied Akerlof's (1970) lemon problem to the equity market. Rock assumed that there are two categories of investors: informed and uninformed investors. According to this theory, underpricing is a way to reduce asymmetric information among investors and assure the participation of retail investors in the bidding process, which are essential for the full subscription of the IPO.

The third and last type of asymmetric information is between the issuer and the underwriter. Loughran and Ritter (2002) mentioned the potential agency problem created by the institutional agreement between these two parties. Baron and Holmström (1980) hypothesized that underwriters are more informed than are issuing companies about market demand. Underwriters can reduce their marketing and distribution efforts by increasing underpricing, and issuers are obliged to accept this lower price since they have less information about investors' demand. Ljungqvist and Wilhelm (2003) demonstrated that underpricing can be reduced through the issuing firm making stricter contractual choices for the purpose of monitoring the underwriting activity.

Theories about asymmetric information contribute to explaining why it is common to encounter underpricing in IPOs. In addition, the underpricing literature comprises other studies intended to establish proxies for the severity of the asymmetric information indirectly influencing the degree of underpricing.

\subsection{Factors affecting information asymmetry}

During an IPO, information asymmetry can be affected by diverse factors, those belonging to either the process itself or the intrinsic characteristics of the company. Among specific firm characteristics, such as firm age and size and the riskiness of the business, corporate governance is identified. Corporate governance regulates the relationships between the main stakeholders within a company, influencing agency dynamics between shareholders and management and conflicts of interest among diverse types of shareholders. Consequently, effective corporate governance is considered able to reduce these conflicts and to signal the quality of the company to external parties (Biswas and Bhuiyan 2008). Since asymmetric information between an issuer and investors is responsible for underpricing (signalling theory), by influencing such information, corporate governance is expected to also affect the degree of underpricing.

A review of the main studies addressing specific corporate governance factors and their effect on the underpricing level follows.

\subsubsection{Corporate governance factors}

Board size and board independence are two of the most relevant characteristics to consider when addressing the relationship between corporate governance and IPO underpricing. Carter et al. (1998), Certo et al. (2001), Howton et al. (2001), Hearn 
(2011), and Yatim (2011) all studied the effects of different board sizes on the extent of underpricing in various countries' IPOs. Unfortunately, the conclusions are still extremely mixed. While the first two studies found a negative relation between board size and underpricing, other authors either showed a positive relation or were not able to demonstrate any dependence at all. More specifically, Certo et al. (2001) justified the significant and negative relationship between board size and underpricing through a resource-based argument. Investors value boards with a greater number of seats because this potentially increases the quantity of resources that the company can access. Conversely, Howton et al. (2001) found a positive relationship between underpricing and board size in West African IPOs and argued that increasing board size exacerbates agency conflict between owners and management, signalling potential problems to investors and thus leading to higher underpricing. One of the most recent studies, conducted by Darmadi and Gunawan in 2012 on a sample of Indonesian IPOs, showed evidence of a negative correlation between board size and IPOs' first-day returns. A larger board size leads to a reduction in information asymmetry between an issuer and investors, making investors willing to pay a higher price in exchange for less uncertainty about firm value.

Mixed results have also been found regarding board independence. The literature reports controversial results related to whether the high independency level of a board improves firm performance. Hermalin and Weisbach (1988), followed by Pearce and Zahra (1992) and MacAvoy and Millstein (1999), stated that a larger number of independent directors makes the monitoring system more effective, thus leading to better firm financial performance. This statement is based on the principal-agent view, according to which misaligned interests may arise between shareholders, i.e., principals, and managers, i.e., agents. Previous studies have proven that these conflicts send a negative signal to investors; reducing these conflicts through the actions of external directors can reduce IPO underpricing. In contrast, according to Fama and Jensen (1983) and Goodstein et al. (1994), boards that are too independent cause a slowdown in companies' decision processes due to excessive control and auditing, which worsen the value of the firm, leading to higher underpricing. Lin and Chuang (2011) showed that in Taiwan, lower levels of underpricing correspond to a higher percentage of independent directors on the board. They debated that external directors reduce so-called principal-principal conflict. This type of conflict is observable in economies where there is no separation between ownership and control: in this scenario, the two parties with potential contrasting interests are controlling shareholders and minority shareholders, with the former playing managerial roles as well. Principal-principal conflict, similar to principal-agent conflict, eventually increases the degree of underpricing since controlling shareholders prefer to offer shares at a lower price to attract an ampler audience. By doing so, they avoid the creation of block holders that may threaten their control over the firm. Filatotchev and Bishop (2002) validated this argument on a sample of 251 UK IPOs, arguing that independent directors can contribute to capturing financial resources during the IPO process, which is essential for increasing the offer price and reducing the extent of underpricing. In contrast, Yatim (2011) did not find any significant effect of board composition on Malaysian IPO underpricing. Finally, Darmadi and Gunawan (2013) discovered a positive relationship between this variable and the 
underpricing of Indonesian IPOs, suggesting that external directors are not able to reduce agency problems and consequently mitigate underpricing.

Ownership structure and its related control mechanisms also play an important role in the reduction in agency costs. As already mentioned, when the separation between ownership and control is not well structured, agency problems between managers and shareholders may arise. Brennan and Franks (1997) defined underpricing as a way to empower managers and increase agency costs, i.e., principalagent conflict, in the context of dispersed ownership. Indeed, underpricing allows for the sale of shares to a larger number of investors, determining a widespread final ownership configuration and avoiding monitoring practices by a large shareholder, i.e., a block holder. Unlike the case of concentrated ownership, which determines a principal-principal conflict and preserves controlling shareholders' interests, in the dispersed ownership context, managers benefit from this practice. Booth and Chua (1996) empirically demonstrated that the objective of underpricing is to obtain a greater dispersion of ownership so that it translates into greater influence on secondary market liquidity. In contrast to these two theories, Stoughton and Zechner (1998) stated that underpricing attracts block holders that can monitor managers' behaviour and reduce agency costs. Pham et al. (2003) and Chen and Strange (2005) studied the effect of ownership concentration on IPO underpricing in the Australian and Chinese markets, respectively, and they both found a negative relationship between these variables. These authors explained the nature of this relation by arguing that larger shareholders are more aware of the true value of the company than are smaller shareholders. However, Venkatesh and Neupane (2006) did not find any evidence of a correlation between ownership structure and the degree of underpricing in IPOs. Finally, Habib and Ljungqvist (2001) studied the existing relationship between underpricing and the magnitude of the dilution faced by pre-IPO shareholders from retained shares. They showed that the greater the extent of dilution factors is, that is, the increase in shares outstanding after an IPO, the smaller the degree of underpricing. This effect can be explained by the pre-IPO shareholders' increasing interest in the discount at which shares are sold as the stake of ownership sold increases.

Regarding control mechanisms, Beatty and Zajac (1994) stated that incentive systems represent an effective tool for aligning managers' behaviours with shareholders' interests in firms that want to go public. Various authors, such as Brickley, Bhagat, and Lease (1985), showed that the use of stock option plans as part of a compensation package positively affects stocks' market value and, more generally, improves firm performance in financial markets. Certo et al. (2003), followed by Sanders and Boivie (2004), revealed that investors appreciate the utilization of incentive systems and take it into account when evaluating IPO firms. They proved that in the US, market incentive systems, i.e., stock options, lead to a reduction in IPO underpricing. This relation was explained in terms of the reduction in moral hazard problems. Interest alignment occurs in companies that assign shares to the $\mathrm{BoD}$, making these companies more valuable to investors and thus reducing the degree of underpricing. Judge et al. (2015) later corroborated this finding, arguing that stock-option-based compensation schemes actually aggravate IPO underpricing.

The presence of institutional investors and/or board members in the ownership structure of a company further impacts the effectiveness of corporate 
governance. It is generally believed that institutional investors, e.g., banks, insurance companies, and pension and hedge funds, improve firm performance through their expertise and financial resources. When institutional investors own part of a company's shares, the monitoring system becomes more developed (Shleifer and Vishny 1986; Velury and Jenkins 2006), overall leading to better corporate governance Gillan and Starks 2003). The extant findings are also ambiguous regarding the effects that institutional investors' ownership has on IPO underpricing. While Kiymaz (2000) identified a negative relation between the extent of institutional investors' holdings and Turkish IPO underpricing, both Bird and Yeung (2010) and Lin and Chuang (2011) demonstrated a positive influence of this factor on Australian and Taiwanese IPO first-day returns, respectively. Kiymaz attributed this result to the alignment of interests between diverse shareholders caused by the presence of institutional investors. Darmadi and Gunawan (2013), in research based on Indonesian IPO issuers, validated Kiymaz's findings by proving the significance of negative interdependence. These findings were supported by the theory that institutional investors improve corporate governance mechanisms, thus reducing information asymmetry at any level.

Board ownership also influences the underpricing phenomenon. Leland and Pyle's (1977) study proved that underpricing is lower when board ownership is higher because, in this case, information asymmetry between the issuer and investors is reduced. Board ownership works as a sort of guarantee for uninformed investors since, by having a stake in the company, they are strongly incentivized to boost performance in the long term. Nevertheless, S. D. Howton, S. W. Howton, and Olson (2001) demonstrated that the relation between board ownership and underpricing is positive. The above authors stated that board members that own shares in a company are willing to leave money on the table at the time of the IPO to make the offering more attractive to investors, who can instead consider the overlap between ownership and control as a reduction in the efficiency of corporate governance control. Furthermore, once a firm becomes well known and appreciated in the market, board members hope to issue secondary offerings at higher prices, and only at that point do they recover the IPO loss.

During the last few years, the impact of female directors on the performance of newly issued shares has received attention. Adam and Ferreira (2009) discovered that on average, in the US market, the presence of women in the boardroom negatively affected firm performance. Ahern and Dittmar (2012) performed an empirical analysis on the Norwegian market, concluding that the constraints imposed by quotas, requiring a certain level of involvement of female directors, had a negative impact on firms' stock value. Reutzel and Belsito (2015) proved that the presence of female directors in boardrooms is seen as a negative feature by investors, and as it increases, underpricing becomes accordingly higher. For this reason, firms with high gender diversity on their BoDs found it more difficult to sell their first issued shares at a high price. Reutzel and Belsito (2015) also demonstrated how this behaviour became less clear in the last years following institutional investors' commitment to increasing diversity within organizations. 


\section{The italian market}

The Italian Stock Exchange is managed by Borsa Italiana S.p.A., part of the London Stock Exchange Group, and includes both regulated and unregulated equity markets. There are two regulated markets, the so-called Mercato Telematico Azionario ("MTA") and Mercato Telematico degli Investment Vehicles ("MIV"). Listed stocks on the MTA are divided into three categories according to companies' dimensions and the specific requirements with which they need to comply to be admitted to the segment. The three categories are blue chip, star and standard. Conversely, the MIV is the regulated market created with the aim of providing investment vehicles with capital, liquidity, and visibility to support their clear strategic vision. As for unregulated markets, Borsa Italiana S.p.A. manages the Multilateral Trading Facilities ("MTF"), which includes the Global Equity Market ("GEM"), the Trading After Hours ("TAH") and the Mercato Alternativo dei Capitali or Alternative Capital Market ("AIM"). The AIM is the market segment reserved for small and medium-sized enterprises ("SMEs") with high growth potential; it is characterized by a straightforward admission process while guaranteeing high visibility internationally. This segment has been invented with the aim of helping Italian SMEs in their internationalization process, providing them with the proper financial resources to compete against their non-Italian adversaries. The MTA and AIM are the primary exchanges for Italian IPOs. The main differences between these two markets concern the admission process and corporate governance, transparency, and disclosure standards to be maintained as belonging to one of these segments, as well as asset liquidity. In particular, companies willing to be listed on the MTA are required to have a minimum capitalization of $€ 40$ million and to offer a minimum free float of $25 \%$; they need to have been established for at least three years and to comply with the corporate governance rules presented in the Italian Financial Act. Moreover, these companies must present to the Italian specific authorities a detailed document called a "prospectus", the veracity of which is ascertained through a complex process of due diligence. The prospectus includes complete information about the issuer and securities offered as well as a detailed list of all the risks involved in both the company issuing the securities and the securities themselves. However, by consulting IPO prospectuses, investors can find audited financial information of the past three financial years, together with an audit report for each year. The AIM also allows for the listing of smaller companies with a requirement of $10 \%$ free float. Companies willing to list their shares on the AIM only need to deliver to Borsa Italiana an Admission Document, which is less detailed than the abovementioned prospectus. In this market, due diligence is not carried out by Italian authorities; it is conducted by a nominated adviser ("NOMAD") who is held responsible for requirement compliance checks. In terms of disclosure requirements after listing, both MTA and AIM listed companies must disclose their annual financial statements and biannual reports to the market. Italian surveillance authorities are the Italian Securities and Exchange Commission ("Consob") and Borsa Italiana S.p.A. Borsa Italiana manages the Italian Stock Exchange by defining the procedures 
that listing companies must follow to approach the equity market and by allowing for or denying their listing on the stock exchange. Consob is an independent supervisory authority whose work is to protect investors and guarantee the transparency and efficiency of Italian financial markets. Regarding the IPO market, Consob is initially responsible for the approval of IPO prospectuses. Then, it supervises the whole IPO process, ensuring that it takes place in accordance with Italian and community rules and regulations. Typically, the Italian IPO process takes from five to seven months, while the listing process on the AIM is simplified and usually takes from three to four months to complete. The first action undertaken by the issuing company is the implementation of corporate governance practices to become compliant with Italian market requirements.

By the end of 2016, 387 companies' shares were traded on the Italian Stock Exchange. More specifically, 244 were listed on the MTA (71 of those belonging to the star segment), 66 were listed on the GEM, and 77 were listed on the AIM. The global capitalization of traded companies was $€ 524,9$ billion, corresponding to $31.8 \%$ of Italy's GDP. During 2016, 14 IPOs were identified: 3 on the MTA and 11 on the AIM. The number of initial public offerings in 2016 was lower than that in previous years, with 26 and 27 in 2014 and 2015, respectively.

With regard to corporate governance, Italian unlisted companies must be compliant with the regulatory framework defined in the Italian Civil Code and in companies' acts of incorporation and bylaws. Conversely, for listed companies, the Civil Code holds its relevance together with Legislative Decree 58/1998, called Testo Unico della Finanza ("TUF"), Consob's rulings and the Code of Self-Regulation ("Codice di Autodisciplina") issued in 1999. This code presents a list of corporate governance rules with which companies can voluntarily decide to comply. However, according to the comply or explain principle, companies have an obligation to notify shareholders and supervisory authorities when they decide not to adopt the Code of Self-Regulation. Their financial statements must include a detailed report including the reasons for this nonadoption as well as implemented activities to respect certain standards of transparency and legality. To date, most listed companies have adopted the code, while only a few unlisted companies have decided to do so. The Code of Self-Regulation mainly addresses the following topics: the characteristics of BoDs and other bodies, risk management procedures, shareholders' relations, and related-party transactions.

Three different models of corporate governance are available to firms eligible for IPO; when bylaws do not require a different structure, the traditional structure applies.

(i) Traditional system: this model requires the presence of a BoD or a sole director as the management body of the company and of a controlling body in charge of guaranteeing that the BoD acts in compliance with the law and the company's statute. Members of both bodies are appointed in a shareholder meeting.

(ii) Monistic system: in this case, shareholders only appoint the BoD that is responsible for managing the company. This board, in turn, appoints a controlling body, selecting at least three people among its own members. To 
guarantee stricter control of board members' behaviour, shareholders are also required to nominate an external auditing body.

(iii) Dualistic system: shareholders appoint a supervisory board with controlling and compliance functions, formed by at least three directors. This board is responsible for appointing the management body, which is composed of a minimum of two members. Similar to the monistic system, in this structure, shareholders nominate an external auditing body.

In addition to the previously mentioned rules, in listed companies, shareholders appoint corporate bodies through a voting procedure that allows shareholders to appoint a certain number of directors on a pro rata basis. Listed companies are also obliged to assure gender diversity within BoDs and to guarantee the appointment of independent directors and directors selected by minority shareholders. For a director to be considered independent, he or she must not have any relation of any type with the corporation or its directors and shareholders, except for his or her commitment on the BoD. Independent directors must meet strict integrity, expertise and independence requirements, similar to those required for statutory auditors.

A summary of the main corporate governance trends ${ }^{2}$ that characterized the Italian market in the reference period is as follows: by the end of $2016,70 \%$ of Italian listed companies were controlled by one or a few shareholders, who hold on average $47 \%$ of the company's shares, demonstrating the existence of a very concentrated ownership system. Among these companies, the majority were characterized by family control, with family members also holding management positions. However, noncontrolled companies, which are companies with very fragmented ownership, accounted for the largest market share in terms of capitalization. In $26.6 \%$ of these companies, institutional investors owned a significant share, presenting a decrease in their relevance compared to previous years, in which this percentage reached approximately $40 \%$. Concerning the separation between ownership and control, it is important to underline how the use of cross-holding and pyramiding structures has largely decreased in recent years, reaching only $18.6 \%$ of the market compared to $39 \%$ in the late 1990 s and $20 \%$ in 2010 . Regarding the dimension of BoDs, by the end of 2016, they were composed on average of 10 members when the traditional model was adopted. The traditional model is the most commonly used model among Italian public companies. On average, independent directors represented approximately $50 \%$ of BoD members. Furthermore, an upward trend was observed in regard to the number of listing or listed companies that established advisory committees internal to their BoDs. For instance, $60 \%$ of listed companies adopted a nomination committee in 2017, compared to only $20 \%$ in 2011 . Moreover, board diversity was strictly correlated with the identity of the majority shareholder. Indeed, when a company is controlled by an institutional investor, this results in a board room composed of younger directors with diverse nationalities, higher academic achievements, and managerial backgrounds. Regarding gender diversity, the percentage of

\footnotetext{
${ }^{2}$ Source: "Rapporto 2017 sulla corporate governance delle società italiane", CONSOB.
} 
female directors among BoD members was continuously increasing, reaching $31 \%$ by the end of June 2016, compared to $18 \%$ in 2013.

\section{Hypotheses}

According to the existing literature on IPO underpricing and corporate governance, together with an analysis of the Italian capital market and the knowledge about the structure of Italian private and public companies, a set of hypotheses have been developed and stand as the basis of the paper.

The hypotheses mainly address $\mathrm{BoD}$ characteristics (H1 to H5), except for two (H6 and H7) that are related to companies' ownership structure to account for Italian market specificities. BoD hypotheses all derive from signalling theory, which defines underpricing as a means for good companies to signal their value in the market, reducing information asymmetry between the issuer and potential investors. Increasing BoD transparency and efficiency works as a substitute for companies in signalling their high quality, allowing them to reduce the degree of underpricing. It follows that the $\mathrm{BoD}$ characteristics that the Italian market considers as being able to increase the quality of a company are expected to be negatively associated with the degree of first-day returns. Ownership structure hypotheses are also based on signalling theory since a particular type of shareholder can signal to external investors the adoption of specific corporate governance procedures, but these investors are also influenced by other theories, proving that the degree of underpricing is influenced by the personal interests of controlling shareholders.

H1: The size of the board of directors is negatively associated with the degree of underpricing of Italian IPOs. The higher the number of directors composing a company's BoD is, the larger the number of potential connections with key people providing more information and other resources to the firm (Certo et al. 2001; Darmadi and Gunawans 2013). By having more people in the boardroom, companies signal more accurate control over management practices and a more reliable internal structure.

$\mathrm{H} 2:$ The independence of the board of directors is negatively associated with the degree of underpricing of Italian IPOs. Italian companies are mainly characterized by little or nonexistent separation between ownership and control, with majority shareholders usually sitting on BoDs. Therefore, this paper's expectation is in line with the research of Lin and Chuang (2011) in a country with a similar ownership/ control structure. The findings of the above research revealed an inverse relation between the number of independent directors and the degree of underpricing of Taiwanese IPOs. Investors attribute a higher value to board independence in companies where the largest shareholders are also in charge of managing the business. In this context, external directors can indeed attenuate the so-called principal-principal conflict.

H3: The presence of female directors in the boardroom is positively associated with the degree of underpricing of Italian IPOs. Due to a cultural heritage that strongly influences today's Italian society, men are considered more efficient than women in leading roles, and the presence of female directors has a negative impact 
on company performance (Ugedo et al. 2019). This social dynamic is also proven by the fact that women's participation in positions of power is still dramatically low in Italy compared to that of men; according to the World Economic Forum's 2017 report on the global gender gap, out of 144 countries, Italy ranked 84 in terms of equal opportunities at work and in politics, education and health. Moreover, a study by Istat, the Italian National Institute of Statistics, conducted on International Women's Day 2018, reported that only $16.4 \%$ of women are sitting on decision-making bodies. Thus, based on these preliminary remarks, this paper expects that the presence of female directors signals uncertainty and potentially worse performance to investors, accordingly leading to higher underpricing.

$\mathrm{H} 4:$ The degree of board ownership is negatively associated with the degree of underpricing of Italian IPOs. The ownership stake held by board members works as a guarantee that the company will perform at full capacity (Leland and Pyle 1977), as it reduces the probability of incurring morally hazardous behaviours, usually generated by a misalignment of interests between shareholders and managers.

H5: The degree of underpricing of Italian IPOs is lower for companies that implemented a stock option incentive plan prior to the IPO. The offering of stock options to BoD members increases a company's reliability in the eyes of investors (Certo et al. 2003; Sanders and Boivie 2004). This incentive system also reduces the moral hazard problem by aligning the interests of the BoD and shareholders (Beatty and Zajac 1994).

H6: The presence of institutional investors is negatively associated with the degree of underpricing of Italian IPOs. Information asymmetry between an issuer and investors is reduced when institutional investors own a certain amount of the company's shares (Kiymaz 2000; Darmadi and Gunawan 2013). This is mainly due to their reputation as professionals following strict procedural rules and responding to tight disclosure requirements, especially in a country like Italy, where most companies are run by families lacking managerial expertise.

H7: Ownership concentration is positively associated with the degree of underpricing of Italian IPOs. When ownership structure is characterized by one or a few shareholders holding the majority of shares, there is an incentive for them to underprice the public offering to obtain more widespread demand and sell shares to a larger number of investors. By doing so, they avoid the creation of a block holder, who can undermine their control over the company (Filatotchev and Bishop 2002). Thus, underpricing is expected to be higher for companies with a more concentred ownership structure.

The aforementioned hypotheses are summarized in the following table (Table 1).

\section{Methodology}

\subsection{Sample selection and sources}

The research question has been addressed using a sample of Italian companies that experienced their first issuance of shares on the Italian stock exchange between the 1 st of January 2000 and the 31 st of December 2016. The starting point of the 


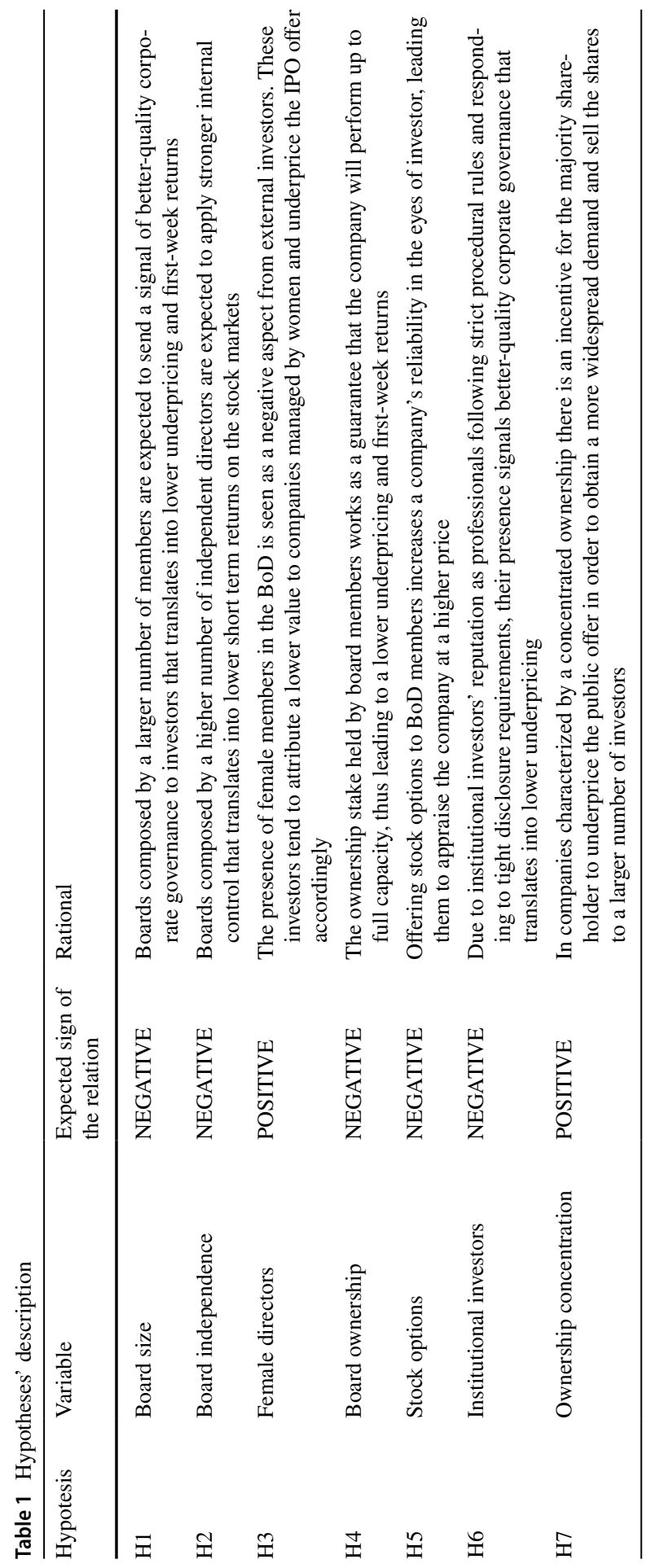


selected timeframe was established considering the introduction of the Corporate Governance Code, which was issued by the Italian Stock Exchange in 1999 (Cirillo et al. 2015), as previous studies have shown how regulatory changes and stricter disclosure requirements affect IPO motivations and performance (Ekkayokkaya and Pengniti 2011; Shi et al. 2013; Akyol et al. 2014; Cattaneo et al. 2015). For the last year of observation, we chose the end of 2016, as several studies have shown that Italian companies had converged by then towards standardized corporate governance models, making regulatory requirements less relevant, with reference to this research's statistical significance, to collect the most recent data. As reported in a study conducted by Zattoni (2020), "In 2017, the several revisions of the code (Corporate Governance Code) and the experience matured by listed companies and investors favoured the evolution of boards of directors coherently with international best practices [...] From this perspective, the code played a key role in pushing shareholders, directors, and managers to develop and adopt good corporate governance practices."

Only listings through public offerings have been considered for the purpose of this analysis. Therefore, secondary offerings, seasoned public offerings, and equity carve-outs are not included in the sample. To date, the selected firms still actively trade their shares either on the MTA or the AIM. The dataset also comprises information regarding issue type, industry, offer price and offer size.

To identify the aforementioned IPOs, the Bloomberg and Thomson Reuters Eikon databases were consulted. The Bloomberg database identified 210 companies that went public on the Milan Stock Exchange between 2000 and 2016. This number of deals does not take into account investment trusts and close-end funds, as well as any of the so-called "financial" companies. This type of corporation is not included in the sample due to its corporate governance rules, which are extremely different from those of companies operating in other industries.

The Thomson Reuters Eikon database has also been used to gather firm-specific information, such as the book value of total assets and net income, as reported according to GAAP standards one accounting period prior to the IPO date. However, this database only reports 145 IPOs with related data in the defined timeframe, causing a sharp reduction in the size of the selected database. Finally, with reference to the corporate governance characteristics of IPO firms, data collection has been performed through the consultation of IPO prospectuses and Consob and Borsa Italiana reports. Due to the lack of availability of some prospectuses or missing information in the documents of admission of companies listed on the AIM, the final number of companies included in the sample is 128 .

\subsection{Regression model}

To verify whether the first-day returns of Italian IPOs are influenced by firms' corporate governance, a regression analysis was performed, following the method used by Darmadi and Gunawan (2013). A linear regression was conducted on a cross-sectional data sample, and two different models were employed. Model (1) was inclusive of the corporate governance explanatory variables. Model (2) comprised some 
control variables that past theories have proven to have a certain effect on stocks' first-day returns. The inclusion of these variables is meant to avoid omitted variable issues and to improve the quality of the overall study. A description of the included variables and employed regression models follows.

\subsubsection{Dependent variable}

Underpricing is computed as the percentage change between the stock price at the end of the first trading day and the price paid by investors for the first allocation of shares, i.e., the offer price (Certo et al. 2001; Yong, Yatim, and Sapian 2001; Jelic, Saadouni and Briston 2001).

\subsubsection{Corporate governance variables}

The variables for BoD characteristics are board size, board independence, female directors, board ownership, and stock options.

Board size is the natural logarithm of the number of directors making up the company's BoD at the end of the pre-IPO year, as reported in the prospectus of each analysed company. Although most studies define board size as the sole number of directors (Eisenberg, Sundgren, and Wells 1998; Andres et al. 2005; Lin and Chuang 2011; Chancharat et al. 2012; Hidayat and Kusumastuti 2014), this research employs the natural logarithm to reduce skewness in the regression model. According to H1, $\beta_{1}$ is expected to be negative.

Board independence is calculated as the percentage of independent directors operating in the boardroom on the IPO date. This computation is in line with most of the related past research (Certo et al. 2001; Daily, Certo and Dalton 2005; Judge et al. 2015). According to $\mathrm{H} 2$, the sign of parameter $\beta_{2}$ is expected to be negative.

Female directors is represented by the number of female directors taking part in the company's BoD on the IPO date (Reutzel and Belsito 2015). According to H3, this study predicts a positive sign for $\beta_{3}$.

Board ownership is the percentage of shares owned by board members at the end of the pre-IPO year (Judge et al. 2015; Lin and Chuang 2011). According to H4, $\beta_{4}$ is expected to be negative.

Stock options is a dummy variable coded as " 1 " if the company used to assign stock options to executive board members as an incentive tool prior to the IPO and "O" otherwise (Beatty and Zajac 1994; Certo et al. 2003; Judge et al. 2015). According to $\mathrm{H} 5$, this study expects $\beta_{5}$ to have a negative sign.

The variables for ownership structure are ownership concentration and institutional investors.

Institutional investors is the percentage of equity controlled by institutional investors, which are identified as banks, trustees, mutual funds, private equity funds, hedge funds and all other institutions that pool their financial resources to acquire securities (Jennings 2005; Cornett, Marcus, Saunders and Tehranian 2007; Aggarwal, Erel, Ferreira and Matos 2011). In line with H6, $\beta_{6}$ is expected to be negative. 
Ownership concentration is calculated as the percentage of shares owned by the largest shareholder (Chen and Strange 2005; Lin and Liu 2009) on the IPO date. According to $\mathrm{H} 7, \beta_{7}$ should be positive.

\subsubsection{Control variables}

Firm age is the natural logarithm of 1 plus the age of the company going public (Megginson and Weiss 1991; Ferretti and Meles 2011). Age is computed as the difference between the IPO date and the company's foundation date. Firm age is considered a proxy for IPOs' ex ante uncertainty since younger companies have fewer solid track records and are exposed to higher risks due to their lack of expertise (Clarkson 1994). Accordingly, the expected relation with the dependent variable is negative.

Firm size is the natural logarithm of the offer size, that is, the proceeds earned by the company as a result of the issuance (Brau et al. 2007). Similar to firm age, firm size is a measure of IPOs' ex ante uncertainty. Larger firms are considered more reliable, and for this reason, their expected relation with underpricing is negative (Beatty and Ritter 1986; Dewan, Shi and Gurbaxani 2007).

Integer price is a dummy variable that takes a value of 1 when the IPO price is an integer and 0 when it is a noninteger. Bradley, Cooney, Jordan and Singh (2004) and Boulton, Smart and Zutter (2009) hypothesized that integer prices derive from a lack of negotiation between a company and an underwriter, thus signalling high uncertainty related to the issuance. The above authors proved that underpricing is higher for IPOs with integer price offers than for offerings with noninteger prices. Accordingly, a positive relation between integer price and the dependent variable is predicted.

Venture-backed is a dichotomous variable that takes the value of "1" when venture capital companies own equity shares of the IPO company and " 0 " otherwise. Previous studies have proven that underpricing is lower in companies backed by venture capitalists than in those not backed by venture capitalists (Megginson and Weiss 1991; Suchard 2009; Engelen and Essen 2010). Thus, the sign of the relation with the dependent variable is expected to be negative.

Family ownership is a dummy variable that is equal to "1" for companies in which the founding family (also taking into account family relationships between partners) holds the majority of shares and " 0 " otherwise. According to Giovannini (2010), a strong presence of family members in shareholders' structure leads to lower levels of firm performance. This effect can be mainly explained by the presence of family members in strategic roles, selected due to their belonging to the family rather than due to their objective competences. It follows that this variable is expected to be positively linked to underpricing, meaning that family-owned companies should show a higher degree of underpricing, as they are supposed to perform worse than their peers.

Profitability is computed as net earnings divided by total assets, i.e., return on assets (ROA), one accounting period prior to the IPO date, as reported on companies' prospectuses. Profitability is a proxy for companies' risk (Beatty and Welch 
1996); thus, its expected relation with the dependent variable is expected to be negative, indicating lower first-day returns for companies with higher ROA.

Secondary shares is calculated as the number of shares offered by selling shareholders divided by the total number of shares offered in the IPO. Boulton et al. (2009) and other researchers have demonstrated that underpricing decreases as the percentage of secondary shares increases. A plausible explanation is that shareholders bear underpricing costs only when offering their own shares in the IPO. Hence, the relation between this variable and the dependent variable is expected to have a negative sign.

Industry risk is a dichotomous variable used to control for companies' riskiness. High-tech firms (classified according to Thomson Reuters Business Classification, "TRBC") are considered riskier than other types because of the nature of such business, and as a consequence, they are associated with a higher degree of underpricing (Benveniste et al. 2003; Dewan, Shi and Gurbaxani 2007; Engelen and Essen 2010). Industry risk takes a value of 1 for high-tech companies and 0 for all other types, and its expected relation with the dependent variable is positive.

Financial crisis is a dummy variable used to control for the period in which the IPO took place, as it was proven that the global financial crisis in 2007 affected stock performance in the Italian shares market (Cirillo et al. 2017). In particular, the variable differs between IPOs that occurred in the precrisis period and those that occurred in the postcrisis period. Financial crisis takes a value of 0 for the former and 1 for the latter. According to previous literature, IPOs are less underpriced in postcrisis periods ( $\mathrm{Li}$ et al. 2018); thus, the coefficient of the relation between this variable and the dependent variable is expected to be negative.

Market segment is a dichotomous variable that takes a value of 1 for IPOs on the AIM and 0 for IPOs on the MTA. Farag et al.'s (2014) research shows severe differences in these two markets, which are able to influence firm performance on stock exchanges. As previously mentioned, companies willing to be listed on the AIM need to comply with less strict disclosure and corporate governance requirements. This, in turn, creates a higher level of asymmetric information between the issuer and potential investors compared to IPOs taking place on the regulated MTA. Consequently, according to signalling theory, IPOs on the AIM are expected to experience higher underpricing than those on the MTA, which is why the relation between market segment and the dependent variable is expected to be positive.

\subsubsection{Regression equation}

The general model is specified as follows:

$$
y_{i}=\beta_{0}+\beta_{1} x_{i 1}+\beta_{2} x_{i 2}+\beta_{3} x_{i 3}+\cdots+\beta_{k} x_{i k}+\varepsilon_{i}
$$

$\beta_{j}$, with $\mathrm{j}=1,2, \ldots, \mathrm{k}$, represents the parameters of the explanatory variables. These parameters are estimated through the ordinary least squares (OLS) method, the aim of which is to minimize the number of squared residuals obtained from the difference between the observed values and expected values generated by the 
employed linear function. As presented in the previous paragraph, two regression models have been used to either prove or refute the established hypotheses.

Model (1)

$$
\begin{aligned}
\text { IPOunder pricing }= & \beta_{0}+\beta_{1}(\text { board size })+\beta_{2}(\text { board independence }) \\
& +\beta_{3}(\text { female directors })+\beta_{4}(\text { board ownership }) \\
& +\beta_{5}(\text { stock options })+\beta_{6}(\text { institutional investors }) \\
& +\beta_{7}(\text { ownership concentration })
\end{aligned}
$$

Model (2)

$$
\begin{aligned}
\text { IPOunderpricing }= & \beta_{0}+\beta_{1}(\text { board size })+\beta_{2}(\text { board independence }) \\
& +\beta_{3}(\text { female directors })+\beta_{4}(\text { board ownership }) \\
& +\beta_{5}(\text { stock options })+\beta_{6}(\text { institutional investors }) \\
& +\beta_{7}(\text { ownership concentration })+\beta_{8}(\text { firm age }) \\
& +\beta_{9}(\text { firm size })+\beta_{10}(\text { integer price })+\beta_{11}(\text { venture }- \text { backed }) \\
& +\beta_{12}(\text { family ownership })+\beta_{13}(\text { profitability }) \\
& +\beta_{14}(\text { secondary shares })+\beta_{15}(\text { industry risk })+\beta_{16}(\text { financial crisis }) \\
& +\beta_{17}(\text { market segment })
\end{aligned}
$$

For the displayed models to work effectively, six assumptions need to hold: zero error mean; constant error variance, i.e., homoscedasticity; no serial correlation; exogeneity; normality; and no perfect multicollinearity. To test for heteroscedasticity, a White test was conducted, and to prove whether the regression model is affected by autocorrelation, i.e., serial correlation, two methods were used: a graphic analysis of residuals' correlogram and the Breusch-Godfrey LM test. Finally, multicollinearity was investigated through a correlation matrix and further explored through the assessment of variance inflator factors (VIFs). Table 2 specifies which tests have been performed for each of these issues, including the results and consequences of this examination. The regression equations presented misspecification issues in terms of heteroscedasticity and autocorrelation. Indeed, both the White test and Bresuch-Godrey test reported p-values close to 0 , which led us to reject the null hypotheses of homoscedasticity and no autocorrelation, respectively. Autocorrelation was also detected through the observation of regressions' correlograms. For this reason, robust standard errors, i.e., heteroskedasticity-robust standard errors (variant $\mathrm{HC} 1$ ), were employed to replace the usual standard errors in the estimation of parameter $\beta_{\mathrm{j}}$. In contrast, both Pearson correlation matrixes and VIF values indicated the absence of multicollinearity, with the former displaying correlation coefficients lower than 0.9 (Dohoo et al. 1997) and the latter showing values below 10 (Lin 2008). 


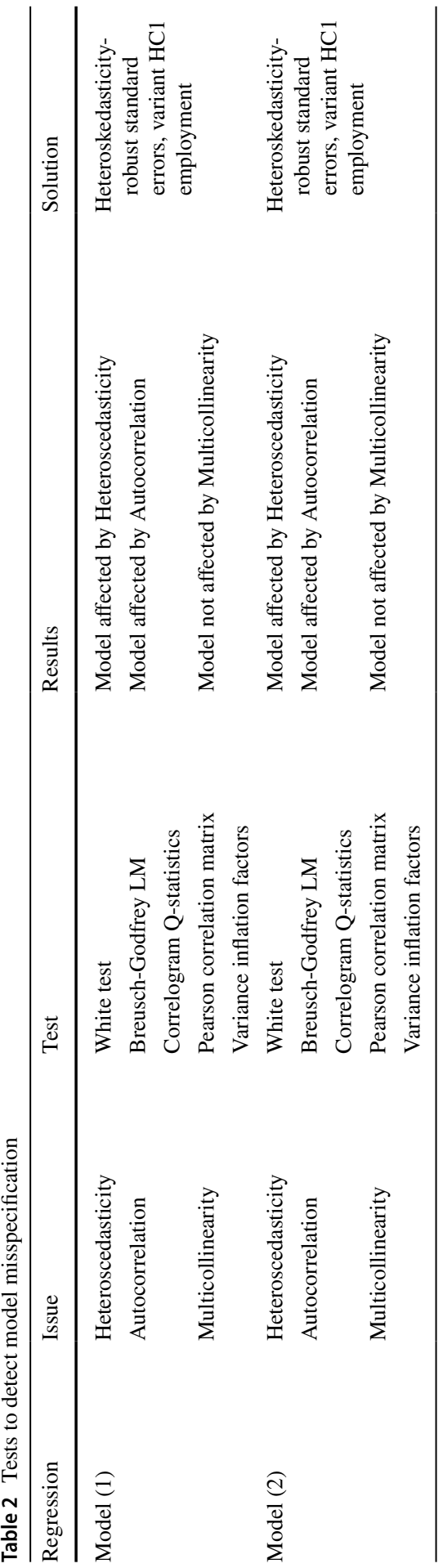


Table 3 IPOs number, mean returns and offer size by year

\begin{tabular}{|c|c|c|c|}
\hline Year & \# IPOs & Underpricing (\%) & Offer size $(€ M)$ \\
\hline 2000 & 21 & 18.56 & 122.70 \\
\hline 2001 & 8 & 1.45 & 386.05 \\
\hline 2002 & 2 & -0.03 & 65.20 \\
\hline 2003 & 2 & -1.88 & 28.78 \\
\hline 2004 & 5 & 5.04 & 447.41 \\
\hline 2005 & 4 & 9.78 & 267.11 \\
\hline 2006 & 13 & 11.94 & 292.72 \\
\hline 2007 & 18 & 2.16 & 167.14 \\
\hline 2008 & 5 & 7.30 & 16.23 \\
\hline 2009 & 3 & 9.38 & 84.76 \\
\hline 2010 & 2 & 15.00 & 23.26 \\
\hline 2011 & 2 & 4.28 & 214.46 \\
\hline 2012 & 3 & 30.30 & 60.05 \\
\hline 2013 & 6 & 14.94 & 177.08 \\
\hline 2014 & 15 & 5.63 & 95.31 \\
\hline 2015 & 13 & 2.24 & 53.26 \\
\hline 2016 & 6 & 6.84 & 93.36 \\
\hline Total & 128 & 8.55 & 161.78 \\
\hline
\end{tabular}

Table 4 Descriptive statistics for underpricing and control variables

\begin{tabular}{llrlrll}
\hline & \# Obs & Mean & Median & Std dev & Min & Max \\
\hline Underpricing (\%) & 128 & 8.55 & 3.37 & 18.73 & -20.00 & 147.00 \\
Firm age (years) & 128 & 31.40 & 17.50 & 33.30 & 0 & 153.00 \\
Firm size (€m) & 128 & 161.78 & 45.50 & 337.53 & 0.87 & 2202.48 \\
Profitability (\%) & 128 & 4.10 & 3.52 & 10.80 & -65.93 & 33.82 \\
Venture backed & 128 & 0.20 & 0 & 0.40 & 0 & 1 \\
Family owned & 128 & 0.63 & 1 & 0.49 & 0 & 1 \\
Integer price & 128 & 0.30 & 0 & 0.46 & 0 & 1 \\
Secondary shares (\%) & 128 & 30.81 & 15.01 & 37.06 & 0 & 100 \\
Industry risk & 128 & 0.20 & 0 & 0.40 & 0 & 1 \\
Financial crisis & 128 & 0.43 & 0 & 0.50 & 0 & 1 \\
Market segment & 128 & 0.27 & 0 & 0.44 & 0 & 1 \\
\hline
\end{tabular}

\subsection{Descriptive statistics}

Data analysis indicated how Italian IPOs were unevenly distributed across years. Accordingly, underpricing values varies from period to period. Table 3 shows a classification of IPOs, short-term returns and offer size by year, identifying 2000, 2006, 2007, 2014 and 2015 as the years with the highest number of IPOs. The decrease in the number of IPOs after 2007 can be explained by the financial crisis. The worsening economic conditions made it less common for private firms to go public and 
Table 5 Descriptive statistics for underpricing and corporate governance variables

\begin{tabular}{llclcll}
\hline & \# Obs & Mean & Median & Std dev & Min & Max \\
\hline Underpricing (\%) & 128 & 8.55 & 3.37 & 18.73 & -20.00 & 147.00 \\
Board size & 128 & 7.31 & 7.00 & 2.82 & 3.00 & 21.00 \\
Board independ. (\%) & 128 & 23.82 & 24.04 & 15.37 & 0 & 80.00 \\
Female directors (\%) & 128 & 9.16 & 0.00 & 12.70 & 0 & 60.00 \\
Own. concent. (\%) & 128 & 67.96 & 67.13 & 26.45 & 18.84 & 100 \\
Board ownership (\%) & 128 & 56.69 & 60.72 & 37.35 & 0 & 100 \\
Institut. investors (\%) & 128 & 11.27 & 0.00 & 24.31 & 0 & 100 \\
Stock options & 128 & 0.42 & 0 & 0.50 & 0 & 1 \\
\hline
\end{tabular}

Table 6 Comparison between underpriced IPOs and overpriced IPOs

\begin{tabular}{llll}
\hline & Underpricing $(\mathrm{n}=84)$ & Overpricing $(\mathrm{n}=37)$ & $\mathrm{p}$-value \\
\hline Board size & $7.1548(2.3872)$ & $7.973(3.617)$ & 0.2134 \\
Board independence & $0.238(0.158)$ & $0.2223(0.1242)$ & 0.5935 \\
Female directors & $0.0862(0.1334)$ & $0.1028(0.1125)$ & 0.5125 \\
Board ownership & $0.5907(0.3616)$ & $0.5774(0.395)$ & 0.8564 \\
Institutional investors & $0.1181(0.2478)$ & $0.0862(0.2162)$ & 0.4991 \\
Ownership concentration & $0.6893(0.2639)$ & $0.6535(0.2576)$ & 0.4892 \\
Firm size & $160.4453(341.25)$ & $159.2434(354.7928)$ & 0.9860 \\
Firm age & $30.7857(31.8672)$ & $34.0270(38.0792)$ & 0.6285 \\
Secondary shares & $0.3538(0.3980)$ & $0.2168(0.2925)$ & $0.0372^{*}$ \\
\hline
\end{tabular}

In brackets standard deviations. ${ }^{*}$ indicate statistical significance (two-tailed) at the $10 \%$ level

bear high costs related to transactions. During the last few years studied, probably due to the, albeit slow, economic recovery, IPOs' frequency returned to the precrisis level. After 2004, the Italian stock market was always affected by underpricing, meaning that issuing firms left money on the table following the IPO process. The mean underpricing percentage for the selected sample of IPOs was $8.55 \%$, which was higher than the $6.52 \%$ identified in a sample of 129 Italian companies that went public from 2001 to 2012 (Dell'Acqua et al. 2015).

Tables 4 and 5 show the summary statistics for underpricing together with the controlling and corporate governance variables, respectively. Clearly, the degree of underpricing widely varied from one firm to another. Firm age was 31 years on average, and mean profitability was $4.10 \%$, calculated as the book value of assets divided by net income. Most companies in the sample were not backed by a venture capitalist and were controlled by founders or relatives on the IPO date; the offer price was usually a noninteger number derived from negotiations between the underwriter and the issuing firm. As shown in Table 5, on average, boards are composed of 7 members; independent directors represent $24 \%$ of board members, while female directors represent only $9 \%$. All the companies selected were 
Table 7 Regression outcome model (1)

Dependent variable: Underpricing

Method: Least squares

Included observations: 128

\begin{tabular}{lccccc}
\hline \multicolumn{1}{l}{ Heteroskedasticity-robust standard errors, variant HC1 } & & \\
& Coefficient & Std. error & t-ratio & p-value \\
\hline Const & 39.8124 & 11.1128 & 3.58 & 0.000 & $* * *$ \\
LnBoardSizeFYO & -16.3171 & 4.4810 & -3.64 & 0.000 & $* * *$ \\
BoardIndependence & 12.3488 & 10.7931 & 1.14 & 0.255 \\
FemaleonBoardFY0 & 3.5524 & 12.6929 & 0.28 & 0.780 \\
BoardOwnership & 4.1694 & 4.8298 & 0.86 & 0.390 \\
StockOptionsD & 2.4518 & 3.3948 & 0.72 & 0.472 \\
InstitutionalInvestorOwnership & 16.5238 & 7.3231 & 2.26 & 0.026 \\
Ownershipconcentration & -11.6996 & 6.1144 & -1.91 & 0.058 \\
R-squared & 0.1450 & Adjusted R-squared & & 0.0952 \\
F (7, 120) & 2.91 & P-value(F) & & 0.0076 \\
\hline
\end{tabular}

Results of the OLS regression of underpricing against the corporate governance variables. OLS standard errors and t-statistics have been corrected using the heteroscedasticity and autocorrelation-consistent method by Newey-West. One, two and three asterisks indicate significance at $0.1,0.05$ and 0.01 level respectively

characterized by concentrated ownership, with the largest shareholder holding on average $68 \%$ of a company's shares. This result is consistent with the peculiarities of Italian companies, mainly small and medium-sized enterprises initiated by families that want to keep property and that are usually also in charge of control activities. With family members being both owners and directors/managers, the mean of board ownership was 57\%, while institutional investors hold on average only $11 \%$ of companies' capital.

In addition, Table 6 presents the t-test outcomes for the differences between IPOs experiencing underpricing and those experiencing overpricing. This analysis has been performed to understand whether there are significant differences in both the controlling and corporate governance variables of firms experiencing diverse underpricing. The number of companies that had underpriced IPOs was 84 , which is in contrast to the 37 IPOs that reported negative first-day returns. Seven companies that on their first day on the stock market traded at the same price as the offer price of the IPO, i.e., 0 first-day returns, were excluded from analysis. Secondary shares was the only variable reporting a significant difference between the two subsamples. Firms experiencing underpricing presented a higher percentage of secondary shares sold in the total offer compared to those experiencing overpricing. 


\section{Empirical results and robustness check}

The following section presents a discussion of the results of this empirical research. Table 7 shows the output of the regression analysis performed using corporate governance explanatory variables only, i.e., Model (1).

As shown in the table, there is a negative relationship between underpricing and the number of directors composing BoDs, implying that the degree of underpricing decreases as the number of directors in the boardroom increases. This finding, in line with this study's expectations (H1), is based on one of the oldest theories about underpricing, called signalling theory (Welch 1989; Allen and Faulhaber 1989; Grinblatt and Hwang 1989; Katherine Spiess and Pettway 1997), according to which underpricing is used as a tool to signal the quality of a company because only highquality issuers can afford to leave money on the table in exchange for future uncertain proceeds. Bad firms cannot take such a risk because they know that the market will reveal their real value once their shares are traded on the stock exchange. Board size is seen as an alternative tool for companies in signalling their quality (Carter et al. 1998; Certo et al. 2001). The significant and negative relationship between board size and underpricing can be explained through a resource-based argument (Certo et al. 2001). Investors value boards with a higher number of seats because this potentially increases the quantity of resources that can be accessed by the company. Moreover, having a larger number of directors in the boardroom is a signal of the stricter monitoring of management activities and, thus, better corporate governance, which finally translates into the better overall quality of the issuing firm (Biswas and Bhuiyan 2008). For these reasons, when the number of directors increases, the firstday returns of an IPO company decrease, implying that the company in question can leave less money on the table during the sale in the primary market.

The percentage of institutional investors in a company ownership structure also significantly affects the degree of underpricing. While H6 predicted a negative relationship between the percentage of shares owned by institutional investors and underpricing, a positive relationship was instead detected in the selected sample of Italian IPOs. Although this result contradicts this study's expectations, it can be explained by focusing on specific characteristics of Italian corporate governance. H6 was based on past studies asserting how institutional investors' presence increases the quality of corporate governance due to their reputation as professionals implementing strict procedural rules and tight disclosure requirements, able to better control management actions (Shleifer and Vishny 1986; Velury and Jenkins 2006; Gillan and Starks 2003). Consequently, their presence was supposed to decrease the underpricing level by representing an alternative signalling tool for external investors (Kiymaz 2000). Nevertheless, the actual result is opposite and has its roots in the research of Lin and Chuang (2011), which demonstrated that institutional investors' ownership is often a means for creating cross-holding and pyramiding, which, as a consequence, increase the control rights of majority shareholders. This phenomenon particularly applies in countries with concentrated ownership, like Italy, where 


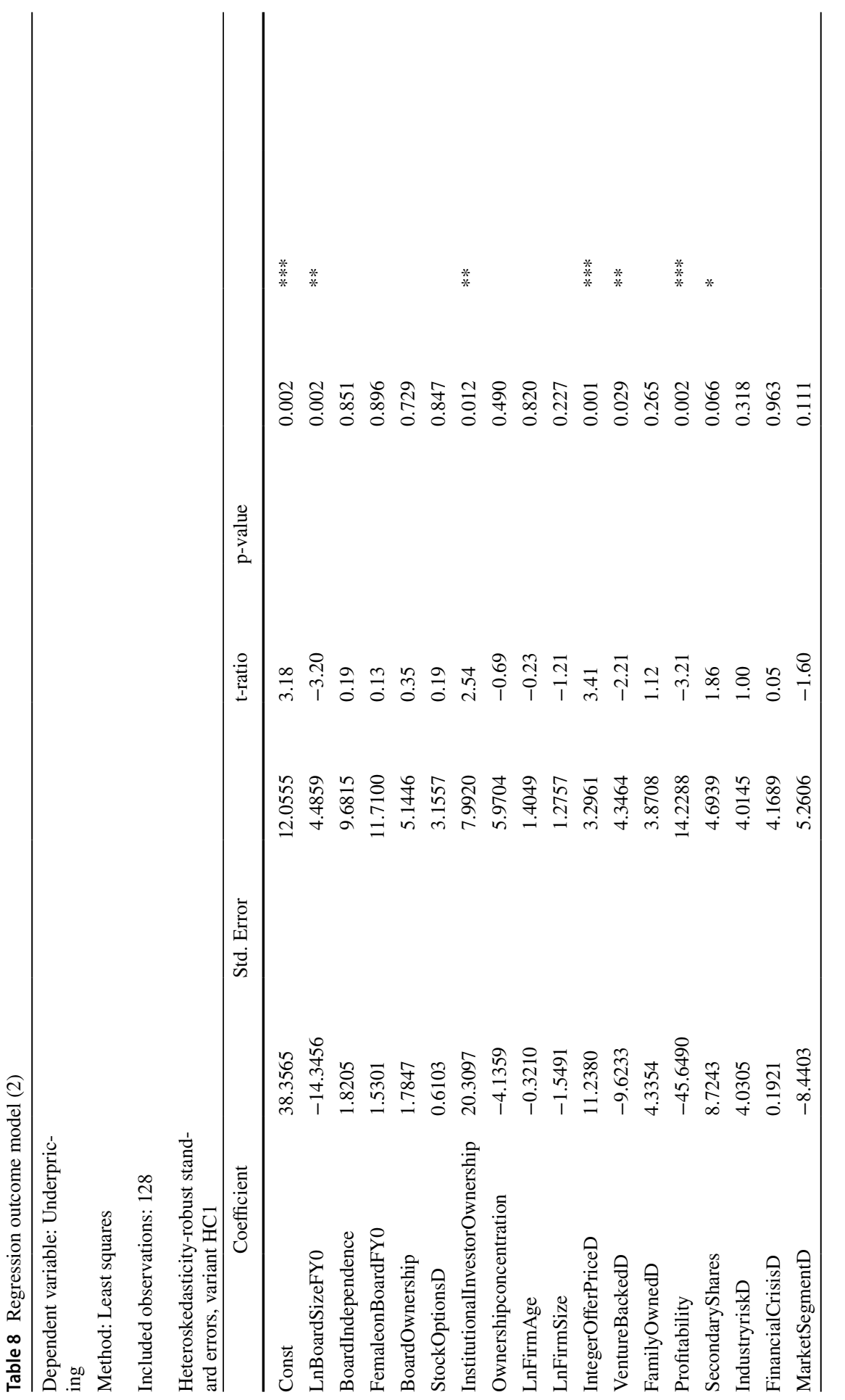




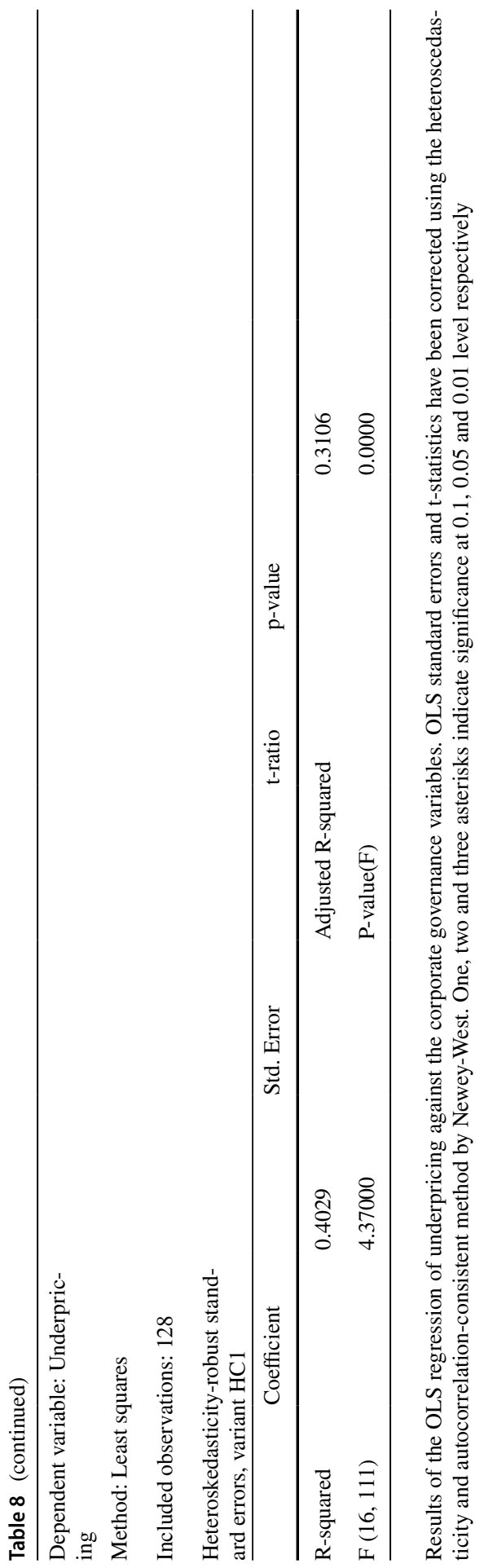


there is no clear distinction between ownership and control, and majority shareholders are usually also in charge of the main managerial activities. This theory is supported by data from the Italian corporate governance market, which showed how, although decreasing, the use of cross-holding and pyramiding structures was largely used in the past, reaching almost $40 \%$ in the late 1990s. In these contexts, through institutional investors, majority shareholders have managed to create complex ownership structures that exacerbate the principal-principal conflict between themselves and minority shareholders, instead of mitigating the agency conflict, an assumption on which H6 was based. Due to the deterioration of internal relationships and the increase in the complexity of the ownership structure, institutional investors' presence worsens the information asymmetry between the issuer and potential investors, thus aggravating the underpricing phenomenon. Furthermore, a negative significant relationship can also be found between ownership concentration and underpricing; thus, if this last variable increases in value, then the level of underpricing decreases.

To increase the explanatory power of our regression analysis, a second model was estimated by including a number of variables that past papers have identified as underpricing determinants, i.e., control variables. Table 8 shows the outcome of Model (2).

As shown in the above table, by adding control variables (i.e., firm age, firm size, integer price, venture-backed, profitability, secondary shares, industry risk, financial crisis, and market segment), the quality of the regression model increases substantially, which is proven by the adjusted R-squared value reaching $31 \%$. The inclusion of control variables in the model did not affect the sign or significance of the corporate governance explanatory variables analysed up to this point, but it showed that these control variables explain the majority of the total variability of the dependent variable. Among all, only integer price, secondary shares, profitability and venture-backed showed significant results. While the first two variables showed positive relations, the last two variables were negatively correlated.

To better interpret and strengthen the results, a robustness check was also performed by choosing the price variation on days 3, 5 and 7 after the IPO as alternative dependent variables for the price variation on day 1 . The results are shown in Tables 12, 13 and 14 in the Appendix. The results of the tests showed perfect robustness for most important variables and good robustness for some control variables. The most important variables that were significant in Models (1) and (2), specifically board size and institutional investors, were still significant in these models. As in the first regression, board size was negatively associated with underpricing, while institutional investors was positively related to underpricing. Additionally, the variable venture-backed confirmed the previous results of Models (1) and (2) in all three regressions, with a negative coefficient.

The models also indicated good robustness for some other control variables that were significant in most models. Among others, in the alternative models, the variable female directors was significant, with a positive coefficient. 


\section{Conclusions}

The aim of this research is to understand whether a company's corporate governance and ownership structure influence its first-day performance on the stock exchange after experiencing an IPO through studying the relationship between these variables and the underpricing phenomenon. To analyse the existent relations, a regression model was constructed, employing first-day returns as the dependent variable. Moreover, to account for the corporate governance and ownership structure of a company, seven explanatory variables were specified: board size, board independence, female directors, board ownership, stock options, institutional investors, and ownership concentration. Throughout the estimation of the two regression models, with the second one including seven control variables in addition to corporate governance variables, it was proven that corporate governance and ownership structure influenced the underpricing of Italian IPOs during the period 2000-2016. In particular, board size was negatively and significantly related to underpricing, while institutional investors' ownership and board ownership had a positive and statistically significant effect. The outcomes of this research support signalling theory, first developed by Ibbotson and Jaffe (1975), which considers underpricing as a tool for reducing information asymmetry between the issuer and potential investors and signalling their high quality. Indeed, this costly tool can be used by good firms that are willing to leave money on the table, confident that they will recoup the money in the future through value creation. While board size acts as a substitute tool for a company in signalling its good quality, its increase leads to a decrease in underpricing, and the intensification of institutional investors' presence and board ownership exacerbates information asymmetry between the issuer and investors, leading to an increase in underpricing.

The empirical findings of this paper contribute to the extant literature on underpricing and corporate governance and are useful for investors willing to invest in Italian IPOs. They can embed this evidence in their investment assessment practice by building a corporate governance model that predicts the degree of underpricing for firms issuing new stocks on the Italian stock exchange. Moreover, this paper is interesting for the management of issuing firms in understanding which corporate governance features are better perceived by the market and how to leverage them to obtain the highest proceed as a result of an IPO. At a broader level, this paper also shows how country-specific characteristics can affect equity markets all over the world. The corporate governance area analysed in this paper represents only a small part of a larger and more complex social system regulated by laws and driven mainly by the cultures and traditions that shape the economic performance of a country. It is extremely important for any actor in the financial system to study and internalize a company's history, habits and mindset to predict equity market movements. 
The main limitation of this paper is the relatively limited sample size. The number of companies included in the sample has been restricted by countryspecific characteristics, with the Italian capital market not being particularly developed and by functional problems in the collection of data. Indeed, it was not possible to collect relevant information for all the companies that went public in the selected time window, with particular reference to those on the AIM. The limited sample size can influence the significance of some variables, hence affecting the final results. The second limitation is represented by the choice of corporate governance variables. Corporate governance can be assessed in various and diverse ways. The variables that we inserted into the model do not fully describe all the characteristics of a company's corporate governance.

Following the aforementioned limitations, future research can focus on a larger sample of companies by including the financial industry and calculating corporate-governance-related variables in different ways, relying less on the consultation of IPO prospectuses. Moreover, the features of a company's corporate governance can be better addressed with the integration of additional variables such as nonexecutive director ownership vs executive director ownership, board reputation, percentage of foreign directors and/or shareholders, and frequency of board meetings. Further investigations can also be performed by employing a cross-country sample to identify how and what country-specific characteristics influence the degree of short-term returns. Finally, it would be interesting to study the impacts of corporate governance features on long-term performance after a company's IPO.

\section{Appendix}

See Tables 9, 10, 11, 12, 13, 14 and Figs. 1 and 2 


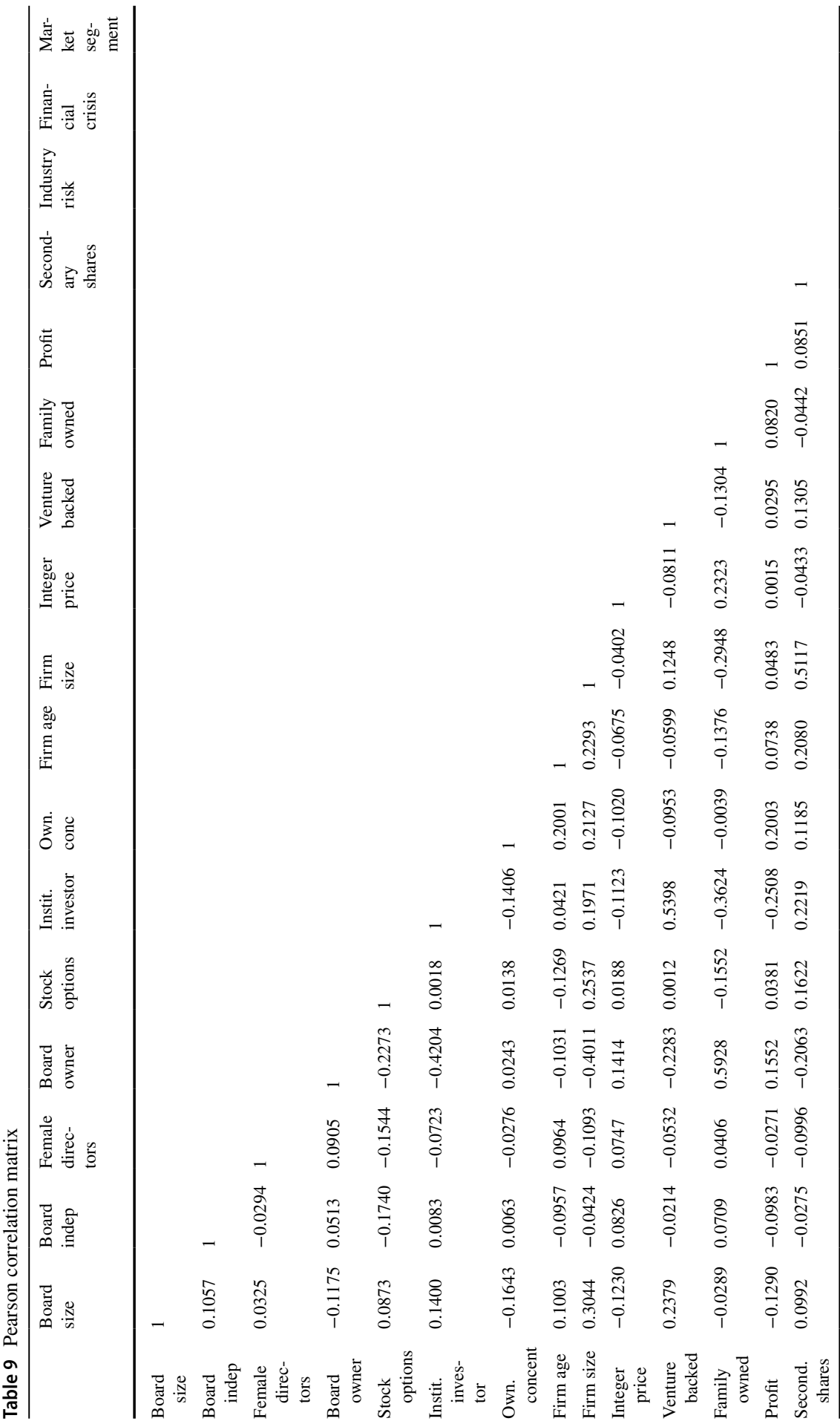




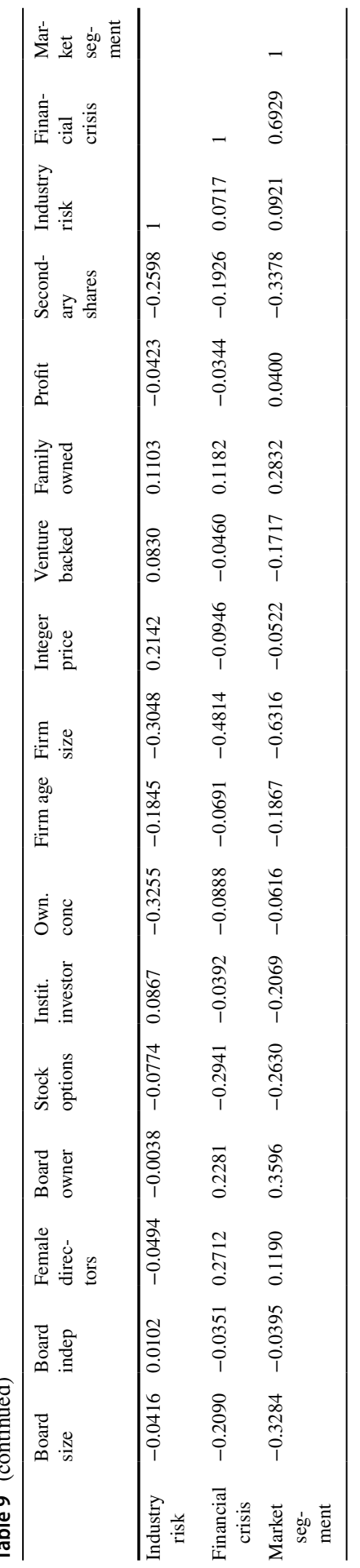


Table 10 VIF values model (1)

\begin{tabular}{lc}
\hline Variable & VIF \\
\hline LnBoardSizeFY0 & 1.08 \\
BoardIndependence & 1.05 \\
FemaleonBoardFY0 & 1.04 \\
BoardOwnership & 1.30 \\
StockOptionsD & 1.13 \\
InstitutionalInvestorOwnership & 1.27 \\
Ownershipconcentration & 1.05 \\
\hline
\end{tabular}

Table 11 VIF values model (2)

\begin{tabular}{lc}
\hline Variable & VIF \\
\hline LnBoardSizeFY0 & 1.41 \\
BoardIndependence & 1.11 \\
FemaleonBoardFY0 & 1.16 \\
BoardOwnership & 1.94 \\
StockOptionsD & 1.29 \\
InstitutionalInvestorOwnership & 1.98 \\
Ownershipconcentration & 1.31 \\
LnFirmAge & 1.25 \\
LnFirmSize & 2.52 \\
IntegerPriceD & 1.22 \\
VentureBackedD & 1.62 \\
FamilyOwnedD & 1.86 \\
Profitability & 1.24 \\
SecondaryShares & 1.59 \\
IndustryriskD & 1.22 \\
FinancialCrisisD & 2.26 \\
MarketSegmentD & 2.86 \\
\hline
\end{tabular}


Table 12 Robustness test (1)

Dependent variable: Offer to 3rd day

Method: Least squares

Included observations: 128

Heteroskedasticity-robust standard errors, variant $\mathrm{HC} 1$

\begin{tabular}{|c|c|c|c|c|c|}
\hline & Coefficient & Std. Error & t-ratio & p-value & \\
\hline Const & 44.4916 & 22.0712 & 2.02 & 0.046 & $* *$ \\
\hline LnBoardSizeFY0 & -17.5440 & 8.2127 & -2.14 & 0.035 & $* *$ \\
\hline BoardIndependence & -2.3226 & 17.7248 & -0.13 & 0.896 & \\
\hline FemaleonBoardFY0 & 42.8098 & 21.4387 & 2.00 & 0.048 & $* *$ \\
\hline BoardOwnership & 5.3044 & 9.4188 & 0.56 & 0.574 & \\
\hline StockOptionsD & 4.4189 & 5.7774 & 0.76 & 0.446 & \\
\hline InstitutionalInvestorOwnership & 28.0015 & 14.6317 & 1.91 & 0.058 & $*$ \\
\hline Ownershipconcentration & -4.4353 & 10.9306 & -0.41 & 0.686 & \\
\hline LnFirmAge & -1.0879 & 2.5721 & -0.42 & 0.673 & \\
\hline LnFirmSize & -2.1068 & 2.3356 & 0.90 & 0.369 & \\
\hline IntegerOfferPriceD & 9.3447 & 6.0345 & 1.55 & 0.124 & \\
\hline VentureBackedD & -15.1413 & 7.9575 & -1.90 & 0.060 & $*$ \\
\hline FamilyOwnedD & 4.9716 & 7.0867 & 0.70 & 0.484 & \\
\hline Profitability & 21.1919 & 26.0502 & 0.81 & 0.418 & \\
\hline SecondaryShares & 1.7571 & 8.5936 & 0.20 & 0.838 & \\
\hline IndustryriskD & 19.8189 & 7.3498 & 2.70 & 0.008 & $* * *$ \\
\hline FinancialCrisisD & -1.6798 & 7.6324 & -22.00 & 0.826 & \\
\hline MarketSegmentD & -12.8072 & 9.6312 & -1.33 & 0.186 & \\
\hline R-squared & 0.2675 & Adjusted R-squared & & 0.1543 & \\
\hline$F(16,111)$ & 2.3600 & P-value $(F)$ & & 0.0040 & \\
\hline
\end{tabular}

Results of the OLS regression of underpricing against the corporate governance variables. OLS standard errors and t-statistics have been corrected using the heteroscedasticity and autocorrelation-consistent method by Newey-West. One, two and three asterisks indicate significance at 0.1, 0.05 and 0.01 level respectively 
Table 13 Robustness test (2)

Dependent variable: Offer to 5th day

Method: Least squares

Included observations: 128

Heteroskedasticity-robust standard errors, variant $\mathrm{HC} 1$

\begin{tabular}{|c|c|c|c|c|c|}
\hline & Coefficient & Std. Error & t-ratio & $\mathrm{p}$-value & \\
\hline Const & 42.0619 & 19.7744 & 2.13 & 0.036 & $* *$ \\
\hline LnBoardSizeFY0 & -16.9136 & 7.3582 & -2.30 & 0.023 & $* *$ \\
\hline BoardIndependence & -3.8546 & 15.8803 & -0.24 & 0.809 & \\
\hline FemaleonBoardFY0 & 38.2829 & 19.2077 & 1.99 & 0.049 & $* *$ \\
\hline BoardOwnership & 4.3677 & 8.4386 & 0.52 & 0.606 & \\
\hline StockOptionsD & 4.5923 & 5.1762 & 0.89 & 0.377 & \\
\hline InstitutionalInvestorOwnership & 25.4081 & 13.1091 & 1.94 & 0.055 & $*$ \\
\hline Ownershipconcentration & -2.8258 & 9.7931 & -0.29 & 0.773 & \\
\hline LnFirmAge & -0.6898 & 2.3045 & -0.30 & 0.765 & \\
\hline LnFirmSize & -1.9249 & 2.0925 & -0.92 & 0.360 & \\
\hline IntegerOfferPriceD & 6.9990 & 5.4065 & 1.29 & 0.198 & \\
\hline VentureBackedD & -13.1472 & 7.1294 & -1.84 & 0.068 & $*$ \\
\hline FamilyOwnedD & 4.6026 & 6.3492 & 0.72 & 0.470 & \\
\hline Profitability & 10.9699 & 23.3393 & 0.47 & 0.639 & \\
\hline SecondaryShares & 2.2740 & 7.6993 & 0.30 & 0.768 & \\
\hline IndustryriskD & 17.8444 & 6.5849 & 2.71 & 0.008 & $* * *$ \\
\hline FinancialCrisisD & -2.6279 & 6.8381 & -0.38 & 0.701 & \\
\hline MarketSegmentD & -11.1541 & 8.6289 & -1.29 & 0.299 & \\
\hline R-squared & 0.2600 & Adjusted R-squared & & 0.1457 & \\
\hline $\mathrm{F}(16,111)$ & 2.2700 & P-value $(F)$ & & 0.0041 & \\
\hline
\end{tabular}

Results of the OLS regression of underpricing against the corporate governance variables. OLS standard errors and t-statistics have been corrected using the heteroscedasticity and autocorrelation-consistent method by Newey-West. One, two and three asterisks indicate significance at $0.1,0.05$ and 0.01 level respectively 
Table 14 Robustness test (3)

Dependent variable: Offer to 7 th day

Method: Least squares

Included observations: 128

Heteroskedasticity-robust standard errors, variant $\mathrm{HC} 1$

\begin{tabular}{lrrrrr}
\hline & Coefficient & Std. Error & t-ratio & p-value \\
\hline Const & 39.5092 & 21.6350 & 1.83 & 0.071 & $*$ \\
LnBoardSizeFY0 & -16.5054 & 8.0504 & -2.05 & 0.043 & $* *$ \\
BoardIndependence & -15.4499 & 17.3745 & -0.89 & 0.376 \\
FemaleonBoardFY0 & 25.9843 & 21.0150 & 1.24 & 0.219 \\
BoardOwnership & 7.3344 & 9.2326 & 0.79 & 0.429 \\
StockOptionsD & 1.8640 & 5.6632 & 0.33 & 0.743 \\
InstitutionalInvestorOwnership & 35.8060 & 13.3425 & 2.50 & 0.014 \\
Ownershipconcentration & -4.0820 & 10.7146 & -0.38 & 0.704 \\
LnFirmAge & -0.1582 & 2.5213 & -0.06 & 0.950 \\
LnFirmSize & -0.9481 & 2.2894 & -0.41 & 0.680 \\
IntegerOfferPriceD & 7.6822 & 5.9152 & 1.30 & 0.197 \\
VentureBackedD & -18.0435 & 7.8002 & -2.31 & 0.023 \\
FamilyOwnedD & 5.6836 & 6.9466 & 0.82 & 0.415 \\
Profitability & 15.5147 & 25.5353 & 0.61 & 0.545 \\
SecondaryShares & -0.5454 & 8.4238 & -0.06 & 0.948 \\
IndustryriskD & 20.5932 & 7.2045 & 2.86 & 0.005 \\
FinancialCrisisD & -7.2521 & 7.4815 & -0.97 & 0.335 \\
MarketSegmentD & -5.9446 & 9.4408 & -0.63 & 0.530 \\
R-squared & 0.2565 & Adjusted R-squared & & 0.1488 \\
F (16, 111) & 2.3100 & P-value(F) & 0.0050 \\
\hline Re & * & & & \\
$* *$
\end{tabular}

Results of the OLS regression of underpricing against the corporate governance variables. OLS standard errors and t-statistics have been corrected using the heteroscedasticity and autocorrelation-consistent method by Newey-West. One, two and three asterisks indicate significance at $0.1,0.05$ and 0.01 level respectively 


\begin{tabular}{|c|c|c|c|c|c|c|c|}
\hline Autocorrelation & Partial Co & orrelation & & $A C$ & PAC & Q-Stat & Prob \\
\hline $1 \longmapsto$ & 1 & $\square$ & 1 & 0.489 & 0.489 & 31.329 & 0.000 \\
\hline $1 \longmapsto$ & 1 & 曰 & 2 & 0.424 & 0.243 & 55.071 & 0.000 \\
\hline $1 \longmapsto$ & 1 & 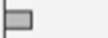 & 3 & 0.445 & 0.236 & 81.384 & 0.000 \\
\hline $1 \square$ & 1 & 1 & 4 & 0.335 & 0.022 & 96.460 & 0.000 \\
\hline $1 \sqsubseteq$ & 1 & 1 & 5 & 0.305 & 0.039 & 109.05 & 0.000 \\
\hline $1 \square$ & 1 & יاط & 6 & 0.340 & 0.112 & 124.81 & 0.000 \\
\hline $1 \square$ & 1 & 1 & 7 & 0.261 & -0.008 & 134.21 & 0.000 \\
\hline $1 \square$ & 1 & 1 & 8 & 0.251 & 0.025 & 142.91 & 0.000 \\
\hline $1 \square$ & 1 & 口 & 9 & 0.331 & 0.146 & 158.20 & 0.000 \\
\hline । & 10 & 1 & 10 & 0.210 & -0.070 & 164.44 & 0.000 \\
\hline 八曰 & 10 & 1 & 11 & 0.171 & -0.055 & 168.62 & 0.000 \\
\hline ı曰 & 1 & 1 & 12 & 0.180 & -0.022 & 173.24 & 0.000 \\
\hline 口 & 1 & 1 & 13 & 0.155 & 0.023 & 176.74 & 0.000 \\
\hline ים 1 & 10 & 1 & 14 & 0.103 & -0.048 & 178.29 & 0.000 \\
\hline ו & 1 & 1 & 15 & 0.120 & -0.007 & 180.41 & 0.000 \\
\hline ים ו & 1 & 1 & 16 & 0.114 & 0.029 & 182.32 & 0.000 \\
\hline ， & 1 & יاط & 17 & 0.170 & 0.127 & 186.67 & 0.000 \\
\hline וp & 10 & 1 & 18 & 0.084 & -0.111 & 187.72 & 0.000 \\
\hline • & 1 & ים & 19 & 0.156 & 0.113 & 191.43 & 0.000 \\
\hline 101 & 미 & 1 & 20 & 0.046 & -0.126 & 191.77 & 0.000 \\
\hline
\end{tabular}

Fig. 1 Residuals' correlogram (1)

\begin{tabular}{|c|c|c|c|c|c|c|}
\hline Autocorrelation & Partial Correlation & & $A C$ & PAC & Q-Stat & Prob \\
\hline $1 \longmapsto$ & $1 \longmapsto$ & 1 & 0.564 & 0.564 & 41.740 & 0.000 \\
\hline $1 \rightleftharpoons$ & 1曰 & 2 & 0.501 & 0.268 & 74.896 & 0.000 \\
\hline $1 \rightleftharpoons$ & 1曰 & 3 & 0.486 & 0.203 & 106.40 & 0.000 \\
\hline $1 \rightleftharpoons$ & 1曰 & 4 & 0.488 & 0.176 & 138.40 & 0.000 \\
\hline $1 \sqsubseteq$ & $1 \mid 1$ & 5 & 0.412 & 0.019 & 161.39 & 0.000 \\
\hline $1 \boxminus$ & 11 & 6 & 0.378 & 0.018 & 180.86 & 0.000 \\
\hline $1 \boxminus$ & 111 & 7 & 0.367 & 0.039 & 199.42 & 0.000 \\
\hline $1 \boxminus$ & $1 \mid 1$ & 8 & 0.345 & 0.022 & 215.93 & 0.000 \\
\hline $1 \boxminus$ & 1 . 1 & 9 & 0.328 & 0.033 & 230.97 & 0.000 \\
\hline ।曰 & 1 1 & 10 & 0.248 & -0.084 & 239.64 & 0.000 \\
\hline 曰口 & 101 & 11 & 0.294 & 0.081 & 251.94 & 0.000 \\
\hline ।曰 & $1 \mid 1$ & 12 & 0.250 & -0.019 & 260.91 & 0.000 \\
\hline $1 \boxminus$ & 111 & 13 & 0.251 & 0.035 & 270.04 & 0.000 \\
\hline 1曰 & \begin{tabular}{l|l}
1 & 1
\end{tabular} & 14 & 0.220 & -0.001 & 277.09 & 0.000 \\
\hline 1曰 & \begin{tabular}{l|l}
1 & 1
\end{tabular} & 15 & 0.213 & -0.005 & 283.78 & 0.000 \\
\hline 口 & 11 & 16 & 0.172 & -0.043 & 288.17 & 0.000 \\
\hline เ曰 & 101 & 17 & 0.208 & 0.068 & 294.64 & 0.000 \\
\hline 1曰 & 101 & 18 & 0.225 & 0.074 & 302.28 & 0.000 \\
\hline 1曰 & \begin{tabular}{l|l}
1 & 1
\end{tabular} & 19 & 0.193 & 0.001 & 307.94 & 0.000 \\
\hline 1 & 111 & 20 & 0.162 & -0.043 & 312.01 & 0.000 \\
\hline
\end{tabular}

Fig. 2 Residuals' correlogram (2) 
Funding Open access funding provided by Università di Pisa within the CRUI-CARE Agreement.

Open Access This article is licensed under a Creative Commons Attribution 4.0 International License, which permits use, sharing, adaptation, distribution and reproduction in any medium or format, as long as you give appropriate credit to the original author(s) and the source, provide a link to the Creative Commons licence, and indicate if changes were made. The images or other third party material in this article are included in the article's Creative Commons licence, unless indicated otherwise in a credit line to the material. If material is not included in the article's Creative Commons licence and your intended use is not permitted by statutory regulation or exceeds the permitted use, you will need to obtain permission directly from the copyright holder. To view a copy of this licence, visit http://creativecommons.org/licen ses/by/4.0/.

\section{References}

Adam, R., \& Ferreira, D. (2009). Women in the boardroom and their impact on governance and performance. Journal of Financial Economics, 94(2), 291-309.

Aggarwal, R. K., Erel, I., Ferreira, M., \& Matos, P. (2011). Does governance travel around the world? Evidence from institutional investors. Journal of Financial Economics, 100(1), 1154-1181.

Ahern, K. R., \& Dittmar, A. K. (2012). The changing of the boards: The impact on firm valuation of mandated female board representation. The Quarterly Journal of Economics, 127(1), 137-197.

Akerlof, G. A. (1970). The market for "Lemons": Quality uncertainty and the market mechanism. The Quarterly Journal of Economic, 84(3), 488-500.

Akyol, A. C., Cooper, T., Meoli, M., \& Vismara, S. (2014). Do regulatory changes affect the underpricing of european IPOs? Journal of Banking and Finance, 45(1), 303-323.

Allen, F., \& Faulhaber, G. R. (1989). Signaling by underpricing in the IPO arket. Journal of Financial Economics, 23, 303-323.

Andres, P. D., Azofra, V., \& Lopez, F. (2005). Corporate boards in OECD countries: Size, composition, functioning and effectiveness. Corporate Governance: An International Review, 13(2), 197-210.

Baron, D. P., \& Holmström, B. (1980). The investment banking contract for new issues under asymmetric information: Delegation and the incentive problem. The Journal of Finance, 35(5), 1115-1138.

Beatty, R. P., \& Ritter, J. R. (1986). Investment banking, reputation, and the underpricing of initial public offerings. Journal of Financial Economics, 15, 213-232.

Beatty, R. P., \& Welch, I. (1996). Issuer expenses and legal liability in initial public offerings. Journal of Law and Economics, 39(2), 545-602.

Beatty, R. P., \& Zajac, E. J. (1994). Top management incentives, monitoring, and risk-bearing: A study of executive compensation, ownership, and board structure in initial public offerings. Administrative Science Quarterly, 39(2), 313-335.

Benveniste, L. M., Ljungqvist, A., Wilhelm, W. J., \& Xiaoyun, Y. (2003). Evidence of information spillovers in the production of investment banking services. The Journal of Finance, 58(2), 577-608.

Bird, R., \& Yeung, D. C. (2010). Institutional ownership and IPO performance: Australian evidence, Financial Management Association, 1-25

Biswas, P. K., \& Bhuiyan, H. U. (2008). Corporate governance and firm performance: Theory and evidence from literature. SSRN Electronic Journal. https://doi.org/10.2139/ssrn.1257617.

Booth, J. R., \& Chua, L. (1996). Ownership dispersion, costly information, and IPO underpricing. Journal of Financial Economics, 41(2), 291-310.

Boulton, T. J., Smart, S. B., \& Zutter, C. J. (2009). IPO underpricing and international corporate governance. Journal of International Business Studies, 41(2), 206-222.

Bradley, D. J., Cooney, J. W., Jordan, B. D., \& Singh, A. K. (2004). Negotiation and the IPO offer price: A comparison of integer vs. non-integer IPOs. Journal of Financial and Quantitative Analysis, 39(3), 517-540.

Brau, J. C., Li, M., \& Shi, J. (2007). Do secondary shares in the IPO process have a negative effect on aftermarket performance? Journal of Banking and Finance, 31(9), 2612-2631.

Brennan, M. J., \& Franks, J. (1997). Underpricing, ownership and control in initial public offerings of equity securities in the UK. Journal of Financial Economics, 45(3), 391-413. 
Brickley, J. A., Bhagat, S., \& Lease, R. C. (1985). The impact of long-range managerial compensation plans on shareholder wealth. Journal of Accounting and Economics, 7(1), 1-5.

Cattaneo, M., Meoli, M., \& Vismara, S. (2015). Financial regulation and IPOs: Evidence from the history of the Italian stock market. Journal of Corporate Finance, 31, 116-131.

Carter, R. B., Dark, F. H., \& Singh, A. K. (1998). Underwriter reputation, initial returns, and the long-run performance of IPO stocks. The Journal of Finance, 53(1), 285-311.

Certo, S. T., Daily, C. M., Cannella, A. A., \& Dalton, D. R. (2003). Giving money to get money: How CEO stock options and CEO equity enhance IPO valuations. The Academy of Management Journal, 46(5), 643-653.

Certo, S. T., Daily, C. M., \& Dalton, D. R. (2001). Signalling firm value through board structure: An investigation of initial public offerings. Entrepreneurship Theory and Practice, 26(2), 33-50.

Chancharat, N., Krishnamurti, C., \& Tian, G. (2012). Board structure and survival of new economy IPO firms. Corporate Governance: An International Review, 20(2), 144-163.

Chen, J., \& Strange, R. (2005). The Determinants of capital structure: Evidence from Chinese listed companies. Economic Change and Restructuring, 38(1), 11-15.

Cirillo, A., Mussolino, D., Romano, M., \& Viganò, R. (2017). A complicated relationship: Family involvement in the top management team and post-IPO survival. Journal of Family Business Strategy, 8(1), 42-56.

Cirillo, A., Romano, M., \& Ardovino, O. (2015). Does family involvement foster IPO value? Empirical analysis on Italian stock market. Management Decision, 53(5), 1125-1154.

Clarkson, P. M. (1994). The underpricing of initial public offerings, ex ante uncertainty, and proxy selection. Accounting \& Finance, 34(2), 67-78.

Cornett, M. M., Marcus, A. J., Saunders, A., \& Tehranian, H. (2007). The impact of institutional ownership on corporate operating performance. Journal of Banking and Finance, 31(6), 1771-1794.

Daily, C. M., Certo, S. T., \& Dalton, D. R. (2005). Investment bankers and IPO pricing: Does prospectus information matter? Journal of Business Venturing, 20(1), 93-111.

Darmadi, S., \& Gunawan, R. (2013). Underpricing, board structure, and ownership: An empirical examination of Indonesian IPO firms. Managerial Finance, 39(2), 181-200.

Dell'Acqua, A., Etro, L. L., Teti, E., \& Murria, M. (2015). IPO underpricing and aftermarket performance in Italy. Journal of Economic \& Financial Studies, 3(3), 1.

Dewan, S., Shi, C., \& Gurbaxani, V. (2007). Investigating the risk-return relationship of information technology investment: Firm-level empirical analysis. Management Science, 53(12), 4-1989.

Dey, A. (2008). Corporate governance and agency conflicts. Journal of Accounting Research, 46(5), 1143-1181.

Dohoo, I., Ducrot, C., Fourichon, C., Donald, A., \& Hurnik, D. (1997). An overview of techniques for dealing with large numbers of independent variables in epidemiologic studies. Preventive Veterinary Medicine, 29(3), 221-239.

Eisenberg, T., Sundgren, S., \& Wells, M. T. (1998). Large board size and decreasing firm value in small firms. Journal of Financial Economics, 48, 35-54.

Ekkayokkaya, M., \& Pengniti, T. (2011). Governance reform and IPO underpricing. Journal of Corporate Finance, 18(2), 238-253.

Engelen, P., \& van Essen, M. (2010). Underpricing of IPOs: Firm-, issue- and country-specific characteristics. Journal of Banking and Finance, 34(8), 1958-1969.

Fama, E. F., \& Jensen, M. C. (1983). Separation of ownership and control. Journal of Law and Economics, 26(2), 301-325.

Farag, H., Mallin, C., \& Ow-Yong, K. (2014). Governance, ownership structure, and performance of entrepreneurial IPOs in AIM companies. Corporate Governance: An International Review, 22(2), $100-115$.

Ferretti, R., \& Meles, A. (2011). Underpricing, wealth loss for pre-existing shareholders and the cost of going public: The role of private equity backing in Italian IPOs. Venture Capital, 13(1), 23-47.

Filatotchev, I., \& Bishop, K. (2002). Board composition, share ownership, and underpricing of U.K. IPO firms. Strategic Management Journal, 23(10), 941-955.

Gillan, S. L., \& Starks, L. T. (2003). Corporate governance, corporate ownership, and the role of institutional investors: A global perspective. Journal of Applied Finance, 13(2), 4.

Giovannini, . (2010). Corporate governance, family ownership and performance. Journal of Management \& Governance, 14(2), 145-166.

Goodstein, J., Gautam, K., \& Boeker, W. (1994). The effects of board size and diversity on strategic change. Strategic Management Journal, 15(3), 241-250. 
Grinblatt, M., \& Hwang, C. Y. (1989). Signaling and the pricing of new issues. Journal of Finance, 44, 393-420.

Habib, M. A., \& Ljungqvist, A. P. (2001). Underpricing and entrepreneurial wealth losses in IPOs: Theory and evidence. The Review of Financial Studies, 14(2), 433-458.

Hearn, B. (2011). The impact of corporate governance measures on the performance of West African IPO firms. Emerging Markets Review, 12(2), 130-151.

Hermalin, B. E., \& Weisbach, M. S. (1988). The determinants of board composition. The RAND Journal of Economics, 19(4), 589-606.

Hidayat, A. W., \& Kusumastuti, R. (2014). The influence of corporate governance structure towards underpricing. International Journal of Administrative Science \& Organization. https://doi.org/10. 20476/jbb.v21i2.4321.

Howton, S. D., Howton, S. W., \& Olson, G. T. (2001). Board ownership and IPO returns. Journal of Economics and Finance, 25(1), 100-114.

Ibbotson, R. G., \& Jaffe, J. F. (1975). Hot issue markets. Journal of Finance, 4, 1027-1042.

Jelic, R., Saadouni, B., \& Briston, R. (2001). Performance of Malaysian IPOs: Underwriters reputation and management earnings forecasts. Pacific-Basin Finance Journal, 9(5), 457-486.

Jennings, W. W. (2005). Further evidence on institutional ownership and corporate value. Advances in Financial Economics, 11, 167-207.

Judge, W. Q., Witt, M. A., Zattoni, A., Talaulicar, T., Chen, J. J., Lewellyn, K., et al. (2015). Corporate governance and IPO underpricing in a cross-national sample: A multilevel knowledge-based view. Strategic Management Journal, 36(8), 1174-1185.

Katherine Spiess, D., \& Pettway, R. H. (1997). The IPO and first seasoned equity sale: Issue proceeds, owner/managers' wealth, and the underpricing signal. Journal of Banking and Finance, 21(7), 967-988.

Kiymaz, H. (2000). The initial and aftermarket performance of IPOs in an emerging market: Evidence from Istanbul stock exchange. Journal of Multinational Financial Management, 10(2), 213-227.

Leland, H. E., \& Pyle, D. H. (1977). Informational asymmetries, financial structure, and financial intermediation. The Journal of Finance, 32(2), 371-387.

Li, R., Liu, W., Liu, Y., \& Tsai, S. (2018). IPO underpricing after the 2008 financial crisis: C study of the chinese stock markets. Sustainability, MDPI, 10(8), 1-13.

Lin, C., \& Chuang, C. (2011). Principal-principal conflicts and IPO pricing in an emerging economy. Corporate Governance: An International Review, 19(6), 585-600.

Lin, F. J. (2008). Solving multicollinearity in the process of fitting regression model using the nested estimate procedure. Quality and Quantity, 42(3), 417-426.

Lin, Z. J., \& Liu, M. (2009). The impact of corporate governance on auditor choice: Evidence from China. Journal of International Accounting, Auditing and Taxation, 18(1), 44-59.

Ljungqvist, A., \& Wilhelm, W. J. (2003). IPO pricing in the dot-com bubble. The Journal of Finance, 58(2), 723-752.

Loughran, T., \& Ritter, J. R. (2002). Why don't issuers get upset about leaving money on the table in IPOs? The Review of Financial Studies, 15(2), 413-444.

MacAvoy, P., \& Millstein, I. (1999). The active board of directors and its effect on the performance of the large publicly traded corporation. Journal of Applied Corporate Finance, 11(4), 8-20.

Megginson, W. L., \& Weiss, K. A. (1991). Venture capitalist certification in initial public offerings. Journal of Finance, 46, 879-903.

Pearce, J. A., II., \& Zahra, S. A. (1992). Board composition from a strategic contingency perspective. The Journal of Management Studies, 29(4), 411.

Pham, P. K., Kalev, P. S., \& Steen, A. B. (2003). Underpricing, stock allocation, ownership structure and post-listing liquidity of newly listed firms. Journal of Banking and Finance, 27(5), 919-947.

Reutzel, C. R., \& Belsito, C. A. (2015). Female directors and IPO underpricing in the US. International Journal of Gender and Entrepreneurship, 7(1), 27-44.

Rock, K. (1986). Why new issues are underpriced. Journal of Financial Economics, 15, 187-212.

Sanders, W. G., \& Boivie, S. (2004). Sorting things out: Valuation of new firms in uncertain markets. Strategic Management Journal, 25(2), 167-186.

Shi, C., Pukthuanthong, K., \& Walker, T. (2013). Does disclosure regulation work? Evidence from international IPO markets. Contemporary Accounting Research, 30(1), 356-387.

Shleifer, A., \& Vishny, R. W. (1986). Large shareholders and corporate control. The Journal of Political Economy, 94(3), 461. 
Stoughton, N., \& Zechner, J. (1998). IPO-mechanisms, monitoring and ownership structure. Journal of Financial Economics, 49(1), 45-77.

Suchard, J. (2009). The impact of venture capital backing on the corporate governance of Australian initial public offerings. Journal of Banking and Finance, 33(4), 765-774.

Martín-Ugedo, J. F., Mínguez-Vera, A., \& Rossi, F. S. (2019). Female directors and firm performance in Italian and Spanish listed firms: Does masculinity matter? Academia Revista Latinoamericana de Administración, 32(3), 411-436.

Velury, U., \& Jenkins, D. S. (2006). Institutional ownership and the quality of earnings. Journal of Business Research, 59(9), 1043-1051.

Venkatesh, S., \& Neupane, S. (2006). Does ownership structure affect IPO underpricing: Evidence from Thai IPOs. Corporate Ownership and Control, 3(2), 106-115.

Welch, I. (1989). Seasoned offerings, imitation costs, and the underpricing of initial public offerings. The Journal of Finance, 44, 421-449.

Yatim, P. (2011). Underpricing and board structures: An investigation of Malaysian initial public offerings (IPOs). Asian Academy of Management Journal of Accounting and Finance, 7(1), 73-93.

Yong, O., Yatim, P., \& Sapian, R. Z. (2001). Initial and long-run performance of new issues on the Malaysian stock market. Corporate Finance Review, 5(6), 28-41.

Zattoni, A. (2020). The evolution of corporate governance in Italy: Formal convergence or path-dependence? Corporate Governance and Research \& Development Studies, 1, 13-35.

Publisher's Note Springer Nature remains neutral with regard to jurisdictional claims in published maps and institutional affiliations. 